ROCZNIKI HUMANISTYCZNE

Volume 66, issue $3-2018$

SELECTED PAPERS IN ENGLISH

DOI: http://dx.doi.org/10.18290/rh.2018.66.3-5e

\author{
ELWIRA KACZYŃSKA \\ KRZYSZTOF TOMASZ WITCZAK
}

\title{
THE THESSALIAN AND CRETAN NAME FOR 'BOTTLE GOURD’
}

In the work entitled Deipnosophistae (Sophists at Dinner) there is an extensive argument of Athenaeus from Naucratis, in which he presents the ancient names of the turnip, known in Polish also as 'kapusta polna' [field cabbage] (Brassica campestris L., syn. Brassica rapa L.). ${ }^{1}$ The ancient erudite grammarian pointed to the numerous dialectal names of this plant. The relevant text reads as follows:

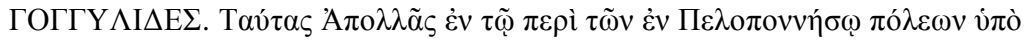

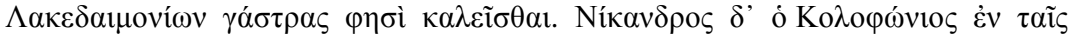

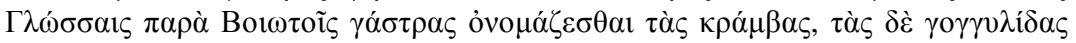

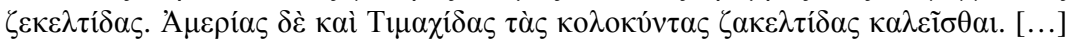

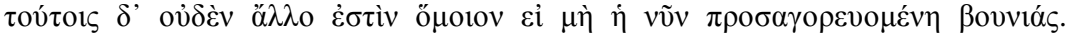

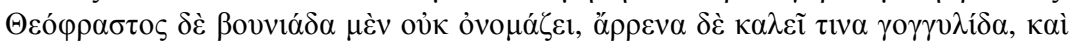

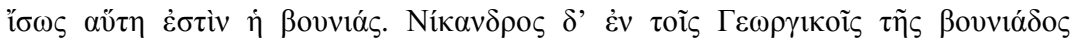
$\mu \nu \eta \mu \mathrm{ov \varepsilon v́ \varepsilon 1.}$

TURNIPS (gongylides). These, as Apollas says in his book On the Cities of Peloponnesus, are called by the Lacedaemonians paunches. But Nicander of Colophon, in his Glossary, says that cabbages are called paunches in Boeotia, while turnips are called zakeltides. Amerias and Timachidas, on the other hand,

Dr. Hab. ElWiRA KACZYŃSKA-professor in the Chair of Classical Philology, University of Łódź; address for correspondence: Katedra Filologii Klasycznej, Wydział Filologiczny, Uniwersytet Łódzki, ul. Pomorska 171/173, 90-236 Łódź; e-mail: aradaina@ gmail.com

Prof. Dr. Hab. KRZYSZTOF TOMASZ WiTCZAK - full profesor in the Department of Latin Studies and Linguistics, Chair of Classical Philology, University of Łódź; address for correspondence: Zakład Latynistyki i Językoznawstwa, Katedra Filologii Klasycznej, Wydział Filologiczny, Uniwersytet Łódzki, ul. Pomorska 171/173, 90-236 Łódź; e-mail: krzysztof.witczak@uni.lodz.pl

The Polish version of the article was published in Roczniki Humanistyczne 63, issue 3 (2015).

${ }^{1}$ Zbigniew PodBIELKOwSKI, Stownik roślin użytkowych (Warszawa: PWRiL 19855), 141 (no. 391). 
say that gourds ${ }^{2}$ are called zekeltides. ${ }^{3}[\ldots]$ There is nothing else similar to these except what is to-day called bounias. Theophrastus, though he does not mention the bounias by name, speaks of a certain turnip which he calls male-turnip (gongylis), and perhaps this is the bounias. Nicander mentions the bounias in the Georgics. ${ }^{4}$

In the quoted fragment, Athenaeus juxtaposes the Attico-Ionian name

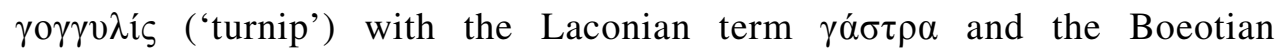
$\zeta \varepsilon \kappa \varepsilon \lambda \tau i$ í. He also points out that the 'male' variety of turnip was called 'ßovviás.' Indeed, botanists distinguish two varieties of turnip, i.e. the longish turnip (subvar. oblonga [Mill.] O.E. Schulz), having an elongated ("male") root, and the common turnip (subvar. depressa [DC.] O.E. Schulz), which is characterized by a short, spherical ("female") root. $^{5}$

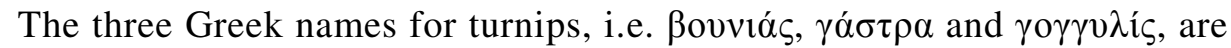
fairly from the etymological and word-formation perspective. The appellative ßovviós f. 'turnip species' ${ }^{6}$ is motivated by the Greek word ßovvós 'hill,

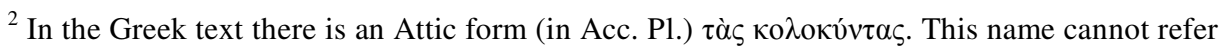
to the squash (Cucurbita pepo L.) or the giant squash (Cucurbita maxima L.), because these plants were brought from America to Europe only in the $16^{\text {th }}$ century, see Otto SCHRADER, Alfons NeHRING, Reallexikon der indogermanischen Altertumskunde, Bd. I (Berlin-Leipzig: Walter de Gruyter, 1917-1923), 652-654; Tadeusz GoRCZYŃSKI (ed.), Rośliny użytkowe (Warszawa: Wiedza Powszechna, 1961), 63. Helmut Genaust categorically claims that "die echten Kürbisse den Alten noch fremd waren“, see Helmut GeNAust, Etymologisches Wörterbuch der botanischen Pflanzennamen (Hamburg: Nikol Verlagsgesellschaft, 2005³), 188-189. In ancient times, the

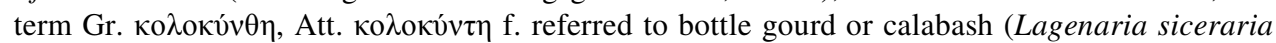
[Molina] Standl., syn. Cucurbita lagenaria L., Lagenaria vulgaris Sér.), see Robert BEEKES, Etymological Dictionary of Greek, vol. I (Leiden-Boston: Brill, 2010), 738-739.

${ }^{3}$ In the quoted translation, the authors of this article have introduced the variant zakeltides attributed to Amerias of Macedonia ( $3^{\text {rd }}$ century BC) and Timachidas of Rhodes ( $1^{\text {st }}$ century BC). It is worth mentioning here the statement by the excellent German philologist Kurt Latte: "Vocalem syllabae primae in A in Ameriae et Timachidae saltem loco $\alpha$ fuisse testator contra Kaibelium

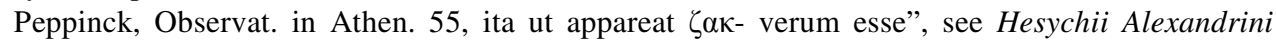
Lexicon, recensuit et emendavit Kurt LATTE, vol. II (Hauniae: Ejnar Munksgaard, 1966), 813.

${ }^{4}$ Athenaeus, The Deipnosophists, vol. 4, with an English translation by Charles Burton Gulick (London: William Heinemann-Cambridge, Mass.: Harvard University Press, 1961) (http://penelope.uchicago.edu/Thayer/E/Roman/Texts/Athenaeus/ home.html).

${ }^{5}$ Zbigniew PodBIELKowsKI, Stownik, 141.

${ }^{6}$ Zofia AbramowiczównA, ed., Stownik grecko-polski, vol. I (Warszawa: PWN, 1958), 438 ('rzepa'); Oktawiusz JuREwICZ, Stownik grecko-polski, vol. I (Warszawa: Wydawnictwo Szkolne PWN, 2000), 154 ('rzepa'); Walther PRELLWITZ, Etymologisches Wörterbuch der griechischen Sprache (Göttingen: Vandenhoeck und Ruprecht, 1892), 51 ('eine längliche Rübenart'). Other dictionaries of Old Greek usually inform that the term Bovviás f. designated 'rapeseed, Brassica napus L.', in particular its cultivated variety 'rutabaga, swede, Brassica napus L. var. napo-brassica L.)', see Иосиф Х. Дворецкий [Iosif Ch. DvoretskiY], Древнегреческо-русский словарь,
} 
knoll'. ${ }^{7}$ Another name for the turnip, Gr. Lac. $\gamma \alpha \dot{\alpha} \sigma \rho \bar{\alpha}^{8}$ is etymologically linked to nouns designating 'abdomen; something bulbous, convex', cf. Gr. Att. $\gamma \alpha \dot{\sigma} \sigma \tau \bar{\alpha}$, Ion. $\gamma \alpha \dot{\sigma} \sigma \rho \eta$ f. 'belly of a vessel, spherical vessel' and $\gamma \alpha \sigma \tau \eta \dot{\rho f}$. 'abdomen, stomach; maternal womb; belly of a vessel' $\left(<* \gamma \rho \alpha \sigma \tau \eta \dot{ }{ }^{*}\right.$, lit. 'glutton, devourer'). ${ }^{9}$ However, due to the popularity of the turnip in the diet of the ancient Greeks, it cannot be excluded that the name was derived directly from the verb $\gamma \rho \alpha \dot{\omega} \omega$ 'bite, chew, eat ${ }^{10}$ through the addition of the

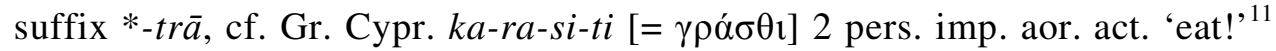
(< IE *gras- 'bite, eat', cf. OInd. grásate 'absorb, swallow, eat', Lat. grāmen

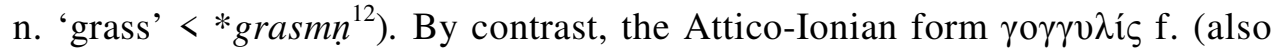

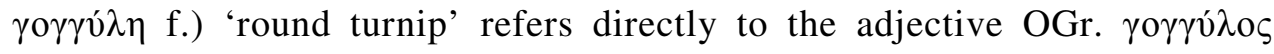

vol. I (Москва: Государственное Издательство Иностранных и Национальных Словарей, 1958), 304 ('брюква'); Francisco Rodríguez AdRADOS, ed., Diccionario griego-español, vol. IV (Madrid: Consejo Superior de Investigaciones Científicas, 1994), 744 ('nabo'); Henry G. LidDELL, Robert ScotT, A Greek-English Lexicon, With a revised supplement (Oxford: Clarendon Press, 1996), 326 ('French turnip'); Franco MonTANARI, Vocabolario della lingua greca (Milano: Loescher Editore, 2003), 418 ('ravizzone'). See also DiosCóRIDES, Plantas y remedios medicinales (De materia medica, libros I-III), introducción, traducción y notas de Manuela García Valdés (Madrid: Editorial Gredos, 1998), 305 ('el nabo').

${ }^{7}$ Émile BoISACQ, Dictionnaire étymologique de la langue grecque étudiée dans ses rapports avec les autres langues indo-européennes (Heidelberg: Carl Winter-Paris: Libraire C. Klincksieck, 1916), 129; Johann B. Hofmann, Etymologisches Wörterbuch des Griechischen (München: Verlag von R. Oldenbourg, 1950), 38, s. v. Bovviós; Albert CARNOY, Dictionnaire étymologique des noms grecs de plantes (Leuven: Publications Universitaires-Institut Orientaliste, 1959), 56; Pierre Chantraine, Dictionnaire étymologique de la langue grecque. Histoire des mots, vol. I (Paris: Éditions Klincksieck, 1968), 190; Robert BEEKES, Etymological Dictionary, 231-232.

${ }^{8}$ The Lakonian name for the turnip has been registered twice in the Hesychian lexicon:

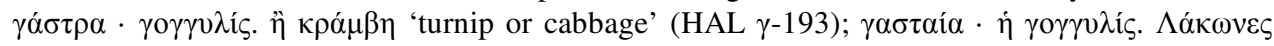
‘turnip. Lakonians' (HAL $\gamma$-204).

${ }_{9}^{9}$ Albert CARnoy, Dictionnaire étymologique, 128; Pierre ChAnTRAIne, Dictionnaire étymologique, vol. I, 212; Robert BEEKES, Etymological Dictionary, 262.

${ }^{10}$ Zofia ABRAMOwiczownA, ed., Stownik, vol. I, 482.

${ }^{11}$ Markus EgETMEYER, Wörterbuch zu den Inschriften im kyprischen Syllabar (Berlin-New York: Walter de Gruyter, 1992), 60; Elwira KACZYNSKA, Krzysztof T. WitCZAK, Cypryjski epigram na wotywnym reliefie z Golgoj (ICS no. 264), in Krystyna BARTOL, Jerzy DANIELEWICZ, eds., Epigram grecki i taciński w kulturze Europy. Konferencja ogólnopolska, Poznań, 11-12 grudnia 1995 (Poznań: Wydawnictwo Naukowe UAM, 1997), 131. The verb Gr. Cypr. $\gamma \rho \alpha ́ \omega$ was

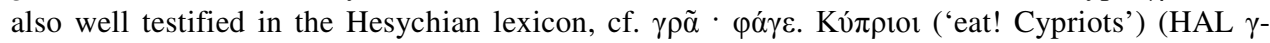

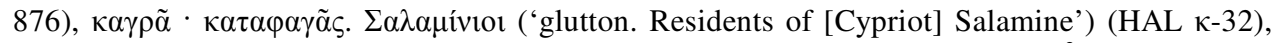
cf. Friedrich Bechtel, Die griechischen Dialekte, Bd. I (Berlin: Weidmann, 1963²), 408.

${ }^{12} \mathrm{Cf}$. Julius POKORNY, Indogermanisches etymologisches Wörterbuch (Bern-München: Francke Verlag, 1959), 404; Helmut RIX, Hrsg., Lexikon der indogermanischen Verben. Die Wurzeln und ihre Primärstammbildungen (Wiesbaden: Dr. Ludwig Reichert Verlag, 2001²), 192. 
'rounded, round'. ${ }^{13}$ The Old Greek name for the turnip is preserved both in the literary Modern Greek language and in numerous contemporary dialects,

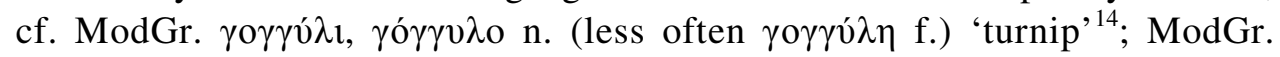

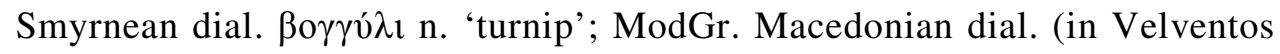

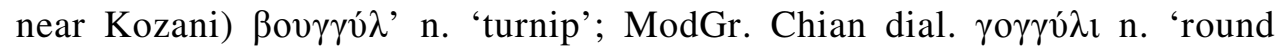

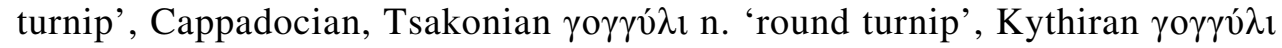

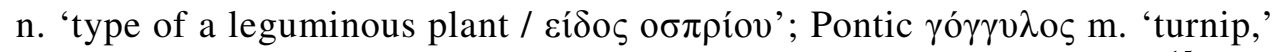

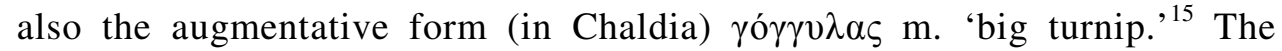

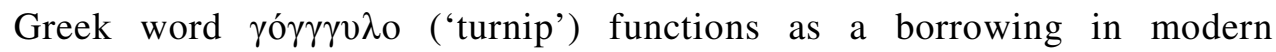
Southern Italian dialects, see It. dial. (North Calabria) gúngulu 'rampion bellflower and its fruit / raperonzolo e il suo frutto. ${ }^{16}$

The fourth (Boeotian) name $\zeta \varepsilon \kappa \varepsilon \lambda \tau i$ ' an equivalent $\zeta \alpha \kappa \varepsilon \lambda \tau i \zeta$, which-as Athenaeus asserts, referring to the lexicographer Amerias of Macedonia ( ${ }^{\text {rd }}$ century BC) and the historian Timachidas of Rhodes ( $1^{\text {st }}$ century BC) - relates to the 'bottle gourd or calabash Lagenaria siceraria (Molina) Standl., syn. Cucurbita lagenaria L.,

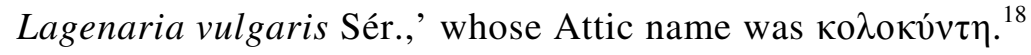

\footnotetext{
${ }^{13}$ Émile BoISACQ, Dictionnaire étymologique, 153; Albert CARNOY, Dictionnaire étymologique, 133; Hjalmar FRISK, Griechisches etymologisches Wörterbuch, Bd. I (Heidelberg: Carl Winter, 1960), 318; Pierre Chantraine, Dictionnaire étymologique, vol. 1, 231; Robert BEEKES, Etymological Dictionary, 271.

${ }^{14}$ Иван П. Хориков, Михаил Г. Малев [Ivan P. KHORiкov, Michail G. MALEv], Новогречес-

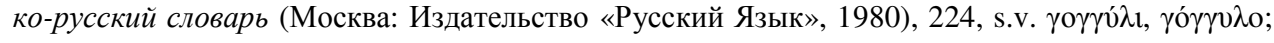

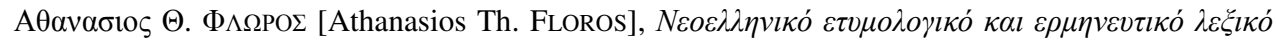

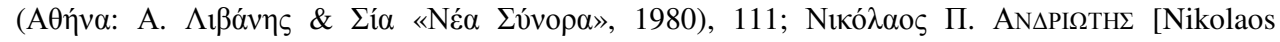

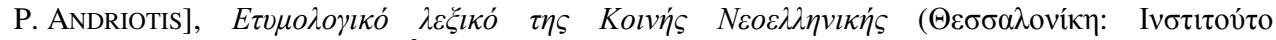

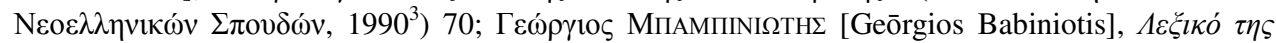

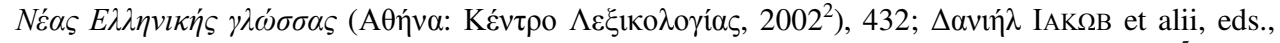

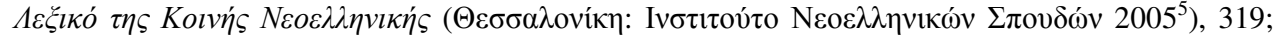

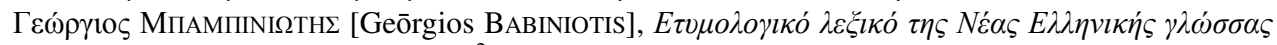

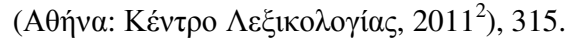

${ }^{15}$ Nikolaos ANDRIOTIS, Lexikon der Archaismen in neugriechischen Dialekten (Vienna:

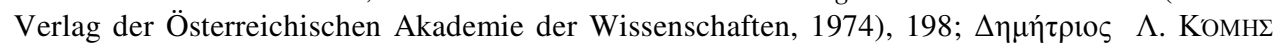

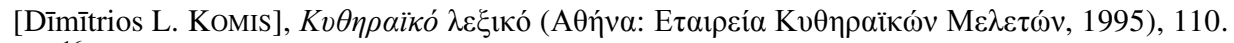

${ }^{16}$ Gerhard RoHLFS, Lexicon Graecanicum Italiae inferioris. Etymologisches Wörterbuch der unteritalienischen Gräzität (Tübingen: Max Niemeyer Verlag, 1964²), 111.

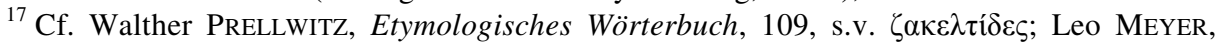
Handbuch der griechischen Etymologie, vol. III (Leipzig: Verlag von S. Hirzel, 1901), 265 ("Dunkler Herkunft. Ob etwa urgriechisch?"); Pierre ChAnTRAine, Dictionnaire étymologique,

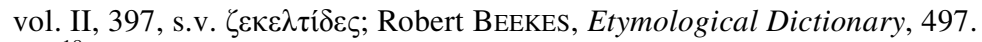

${ }^{18}$ Athenaeus, Deipnosophistae, (II 59c) explicitly states that "Attic writers use one word, colocynth, for them all". It is worth noting that the cognate Ionian form ко calabash' had a dental aspirate sound $\left[\mathrm{t}^{\mathrm{h}}\right]$, see Pierre Chantraine, Dictionnaire étymologique,
} 


\section{THE THESSALIAN ORIGIN OF THE APPELLATIVE ZAKE $\Lambda$ TI $\Sigma$}

Robert Beekes puts forward a convincing thesis that the Boeotian name $\zeta \varepsilon \kappa \varepsilon \lambda \tau i ́ \delta \varepsilon \varsigma$ f. Pl. ('turnips'), similarly to its variant $\zeta \alpha \kappa \varepsilon \lambda \tau i \delta \varepsilon \varsigma$ ('gourds'),

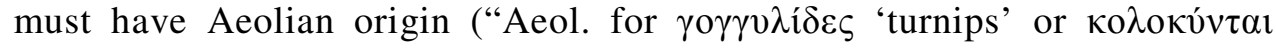
'gourds, ${ }^{19}$ ). Indeed, these two forms do not appear in the preserved works written in Attic or Ionian dialects, or Hellenistic Koiné. The Aeolian origin

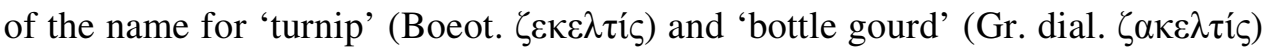
is probably based on the hypothesis of the presence in these phytonyms of the Aeolian intensifying prefix $* \zeta \alpha-$ 'very ${ }^{20}(=$ Gr. Att.-Ion. $\delta 1 \alpha-)$, cf. Lesb. $\zeta \alpha \beta \beta \alpha \tau o \zeta$ (= Att.-Ion. $\delta 1 \alpha \beta \alpha \tau o ́ \varsigma$ ) adj. 'passable, easily reachable,' Lesb.

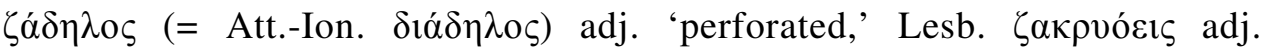

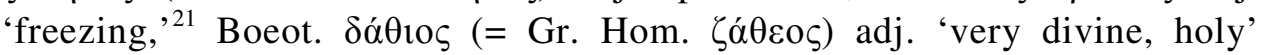
$(<$ OBoeot. $* \zeta \alpha-<\delta 1 \alpha-){ }^{22}$

vol. II, 557; Adriana QuATTORDIO MORESCHINI, Le formazioni nominali greche in -nth- (Roma: Edizioni dell'Ateneo, 1984), 55-56; Robert BEEKES, Etymological Dictionary, 738-739.

${ }^{19}$ Robert BEEKES, Etymological Dictionary, 497.

${ }^{20}$ The dictionary of Hesychius of Alexandria registers the intensifying prefix $\zeta \alpha$ - as an

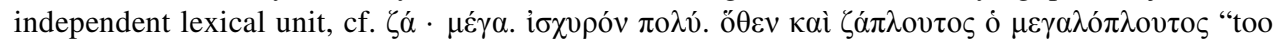
much, too many, greatly. Hence zaplutos also means very rich" (HAL $\zeta-1$ ), see Kurt LATTE, ed., Hesychii Alexandrini, Bd. II, 257.

${ }^{21}$ Zofia Abramowiczówna, ed., Stownik grecko-polski, vol. II (Warszawa: PWN, 1960),

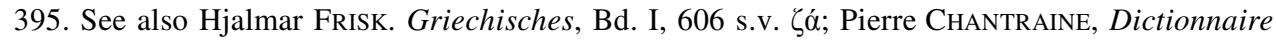

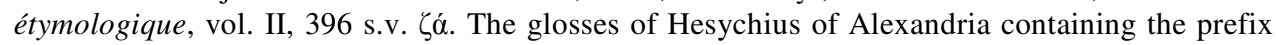

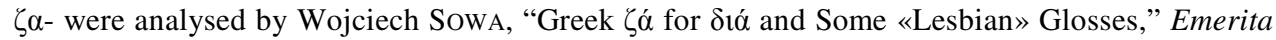
vol. 2, no 77 (2009): 271-294, concluding that "they all (except for special cases for $\zeta \dot{\alpha} \gamma \rho \eta$ and $\zeta \alpha \dot{\alpha} \varepsilon \delta$ ov) belong to the poetical diction". It seems that some of the discussed glosses may have Mycenaean origin and derive from the pre-Homerican epic tradition. However, it cannot be excluded that some of Hesychius' glosses were taken from the Thessalian or Boeotian dialect through the work of Amerias of Macedonia.

${ }^{22}$ The (late) Boeotian form $\delta \alpha$ - $-\theta 10 \varsigma$ can be found in the works by the poetess Corinna of Tanagra (1.I.13 P.). The Berlin Papyrus from the $2^{\text {nd }}$ century AD (P. Berol. 13284), which contains fragments of her works, shows some features of the Boeotian dialect characteristic of the Hellenistic period $\left(3^{\text {rd }}\right.$ or $2^{\text {nd }}$ century $B C$ ). There is no doubt that the Boeotian prefix $\delta \alpha-$ represents a previous Old Boeotian form $* \zeta \alpha-(<\mathrm{Gr}$. $\delta 1 \alpha-)$, as the Greek phoneme $\zeta$ [dz] was

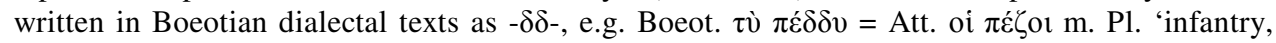

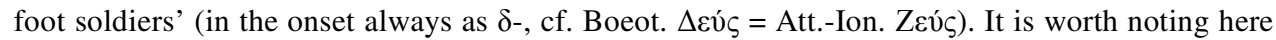
that Hesychius of Alexandria registers the Old Boeotian form $\tau \rho i ́ \pi \varepsilon \zeta \alpha$ f. 'table' (HAL $\tau-1414$ :

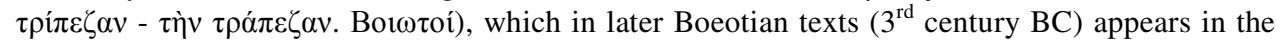
form of $\tau \rho \varepsilon ́ \pi \varepsilon \delta \delta \alpha \mathrm{f}$. 'table' (Antonín BARTONĚK, Chréstomatie starořeckých nářečních nápisů (Brno: Masarykova Univerzita, 2011), 85, 114) with the regular Aeolian shift from - $\rho$ - to - $\rho \varepsilon-$ and the conversion of the phoneme $\zeta[\mathrm{d}]$ into $\delta \delta$ [dd], probably through an intermediate form $\sigma \delta$

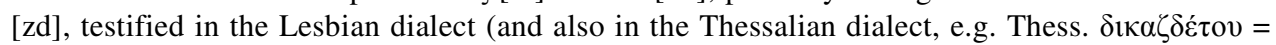

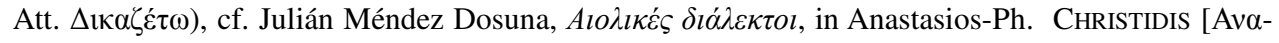


Using the method of elimination, based on the stabilised and thorough knowledge of Greek dialectology, we can successfully assign the name $\zeta \alpha \kappa \varepsilon \lambda \tau i$ ('gourd') to the Thessalian dialect. The group of Aeolian dialects is composed of three idiolects-Boeotian, Lesbian and Thessalian. It can be easily demonstrated that neither Boeotian, nor Lesbian origin of the word

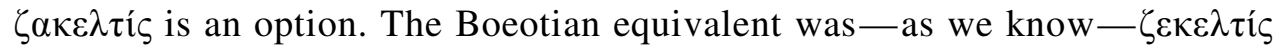
and designated another plant, i.e. turnip. The Lesbian dialect, in turn, has introduced two extremely important innovations that we do not see in the

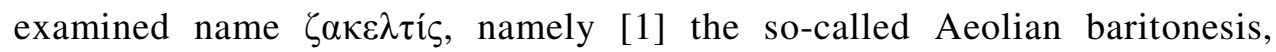
which consists in shifting the stress as far from the end as possible, ${ }^{23}$ and [2] the spirantization of the dental consonant $\tau$ [t] before the front vowel $\mathrm{i}[\mathrm{i}] .^{24}$ The expected Lesbian equivalent would thus have to take on a hypothetical

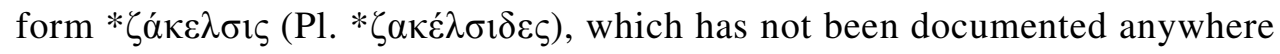
in literary and epigraphic texts. In this situation, we can assume that the term $\zeta \alpha \kappa \varepsilon \lambda \tau i \zeta(\mathrm{Pl}$. $\zeta \alpha \kappa \varepsilon \lambda \tau i \delta \varepsilon \varsigma)$ is of Thessalian origin ${ }^{25}$, and that it found its way into Greek literature owing to the Greek lexicographer Amerias of Macedonia $\left(3^{\text {rd }}\right.$ century BC), whose writings influenced both Timachidas of Rhodes $\left(1^{\text {st }}\right.$ century BC) and Athenaeus of Egyptian Naucratis $\left(3^{\text {rd }}\right.$ century AD).

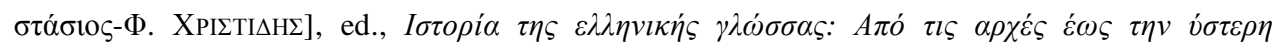

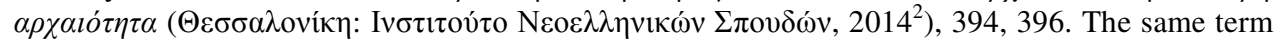
can be found in the Mycenaean dialect as to-pe-za [tórpedza] f. 'table' < Proto-Gr. * $\left(k^{w}\right) t r$-ped-jă f. 'table' (lit. 'four-legged; with four legs'), and in the Attico-Ionian dialects as $\tau \rho \alpha ́ \pi \varepsilon \zeta \alpha$ f. 'table in the dining room; banker's table, counter, exchange office.'

${ }^{23}$ Vittore PISANI, Manuale storico della lingua greca (Brescia: Paideia Editrice, 1973), 60; Oktawiusz JuREwICZ, Gramatyka historyczna języka greckiego (Warszawa: Wydawnictwo Naukowe PWN, 1999²), 58-59; Stephen Colvin, A Historical Greek Reader. Mycenaean to the Koiné (Oxford-New York: Oxford University Press, 2007), 42.

${ }^{24}$ Carl D. Buck, The Greek Dialects. Grammar, Selected Inscriptions, Glossary (Bristol: Bristol Classical Press, 2009), 149; Joseph VENDRYes, Traité de grammaire comparée des langues classiques (Paris: Librairie Ancienne Honoré Champion, 1960), 63. Helmut Rix believes that the assibilation $\tau \imath>\sigma \mathrm{l}$ occurred in the Lesbian dialect under the Ionian influence ("durch Einfluß des Ion."), see Helmut RIX, Historische Grammatik des Griechischen. Laut- und Formenlehre (Darmstadt: Wissenschaftliche Buchgesellschaft, 1992), 89.

${ }^{25}$ The Attico-Ionian and Achaean origin of the considered form $\zeta \alpha \kappa \varepsilon \lambda \tau i \delta \varepsilon \varsigma$ must be excluded due to the preservation of the dental plosive $\tau$ [t] before the vowel $\mathbf{i}$ [i]. In turn, the word initial $\zeta \alpha-(<\delta 1 \alpha-)$ is possible in Aeolian and Achaean, but not in Doric or Attico-Ionian dialect, where $\delta 1 \alpha$ - was preserved. It should be noted that the epigraphic texts from the area of Thessaly do not register the presence of the intensifying prefix $\zeta \alpha$-. Thus, its occurrence is only presumed. In the inscriptions from the $3^{\text {rd }}-2^{\text {nd }}$ century $\mathrm{BC}$ found in Krannon (in the Thessalian district of Pelasgiotis) there appears the preposition $\delta i \varepsilon ́$ (= Att.-Ion. $\delta i \alpha$ ) with the word final vocalism $[\varepsilon]$, see

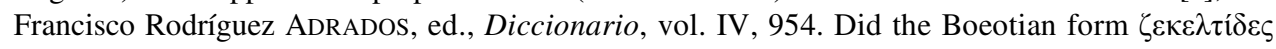
'turnips' contain the same secondary vocalism? 


\section{DIALECTAL NAMES FOR 'TURNIP/ BOTTLE GOURD’ IN THE LIGHT OF LEXICOGRAPHIC SOURCES}

The name turnip or gourd has been certified twice in the lexicon of rare and obscure words, created at the end of the $5^{\text {th }}$ century AD by Hesychius of Alexandria ${ }^{26}$ :

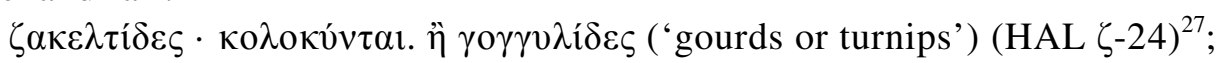

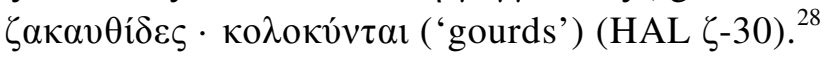

These glosses differ in several details, which require additional explanation and a linguistic commentary, but their similarity and convergent meaning makes it possible to regard them as dialectal variants deriving from a single archetype.

The gloss, recorded in the Byzantine lexicographic source, attributes a related word to the inhabitants of Lydia:

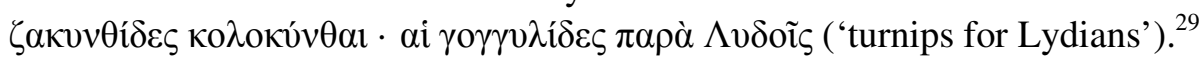

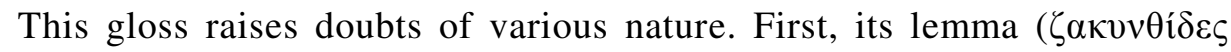

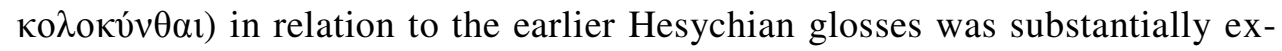

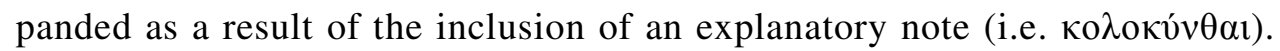
Secondly, the expansion of the lemma made it possible to treat the initial component as a feminine adjective $\zeta \alpha \kappa v v \theta i{ }^{3},{ }^{30}$ created from the proper name Zakynthos (Gr. ZákvvӨos), designating a large Greek island in the Ionian

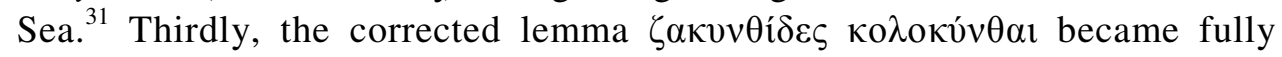

\footnotetext{
${ }^{26}$ A noteworthy editorial commentary refers to both of these glosses, see Kurt LATTE, ed., Hesychii Alexandrini, Bd. II, 812-813.

${ }^{27}$ Ibid., 257.

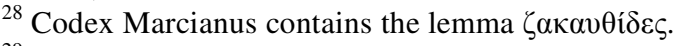

${ }^{29}$ Immanuel BEKKER, ed., Anecdota Graeca, vol. I: Lexica Segueriana (Berolini: G.C. Nauck, 1814), 261. Roberto Gusmani, Lydisches Wörterbuch mit grammatischer Skizze und Inschriftensammlung (Heidelberg: Carl Winter, 1964), 273, cites the Lydian gloss in a different form:

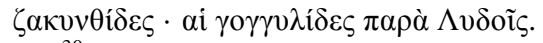

${ }^{30}$ This female form has no confirmation in ancient texts. Stephanus of Bizantium gives one

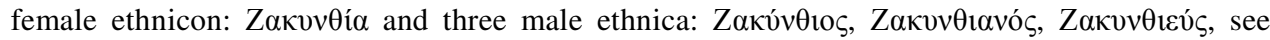
August MeINEKE, ed., Stephani Byzantinii Ethnicorum quae supersunt (Chicago (Illinois): Ares Publishers, 1992), 294 (reprint of the 1849 edition). It should be noted, however, that the female equivalent of male ethnica ending with -عv́ $\varsigma$ were adjectival derivatives built with the help of the

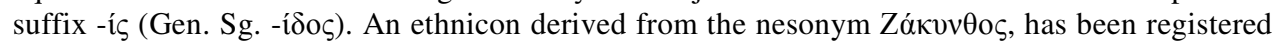
already in the second millennium BC in the linear texts B of Pylos and Mycenae, cf. Gr. Myc. $z a-$ $k u$-si-ja [ckakunsija] Nom. Pl. n. (PY Sa751; PY Sa 787.B), za-ku-si-jo [czakunsijōi] Dat. Sg. (MY Oe 122). See Francisco Aura Jorro, ed., Diccionario micénico, vol. II (Madrid: Consejo Superior de Investigaciones Científicas, 1993), 454.

${ }^{31}$ Zdzisław PISZCZEK, ed., Mała encyklopedia kultury antycznej (Warszawa: PWN, 19907), 799. In ancient times, the name ZókvvӨo
} 
understandable in the Greek context ('Zakynthian gourds'), which did not require any explication or comment. Fourthly, a typically Greek and fully

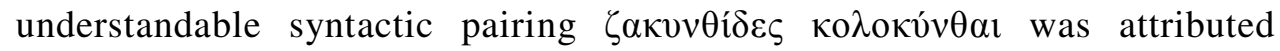
(which is particularly surprising!) to the ancient Lydians, i.e. to the nonGreek population inhabiting Anatolia. It is difficult to accept the speculation that the barbarian population preserved the original Greek expression with its rather unambiguous motivation, while the Greeks themselves (the Boeotians and Thessalonians) changed the name of the turnip (in relation to the bottle gourd) to such an extent that it became completely obscure.

These observations lead to an important conclusion. The version $\zeta \alpha \kappa v v \theta i \delta \varepsilon \varsigma$ has no objective value and is based on the unjustified invention of an unknown, medieval lexicographer who attributed the name 'turnip' to the Lydians probably only because, in the Byzantine era, the population inhabiting the geographical region of Lydia was already completely Hellenized. In this situation, the attempt to derive the allegedly Lydian term for 'turnip' from the name of the island of Zakynthos seems to be absolutely

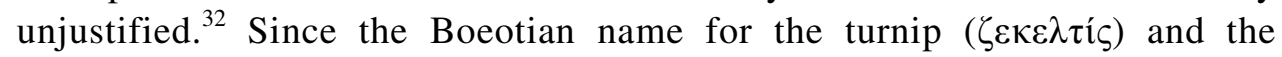

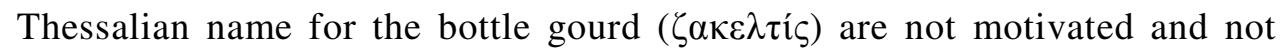
explained in the Greek context, it is difficult to expect that the foreign (Lydian) appellative preserves the correct and uncontaminated Hellenic (Aeolian) form.

In the previous studies, little attention has been given to the form $\zeta \alpha \kappa \alpha v \theta i ́ \delta \varepsilon \varsigma$ preserved in Codex Marcianus, which without justification was

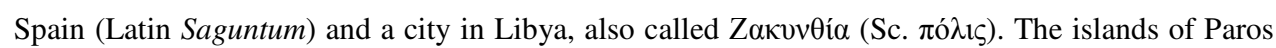
and Delos used to be called ZákvvӨo̧, see Gustav E. BENSELER, Wörterbuch der griechischen Eigennamen (Braunschweig: Verlag von Friedrich Vieweg und Sohn, 1884 ${ }^{3}$ ), 437. It is worth noting that on Delos there is a mountain once called Kynthos (Old Gr. Kv́v $\theta$ os), cf. Elwira KACZYŃSKA, ““'Cieszcie się kozy! Rozejm ogłasza bogini”. Uwagi krytyczne do jednego z epigramatów Kallimacha (62 Pfeiffer = 61 Gow-Page)," Meander 54, is. 5 (1999): 421-428.

${ }^{32}$ Albert J. Van WindeKEns, Contribution à l'étude de l'onomastique pélasgique (Louvain: Publications Universitaires-Institut Orientaliste, 1954), 54-57, proposes a "Pelasgic" etymology for the island of Zakynthos, from which also derives the name of the bottle gourd. Albert CARNOY, Dictionnaire étymologique, 274, s.v. zacynthis, quotes the above explanation ("fruit cultivé dans l'île de Zacynthos"), but he adds a double question mark. At the same time, the Belgian scholar does not exclude oriental borrowing from Anatolian or Aegean sources. In a later work, the same researcher, having rejected the origin of the plant name from the nesonym ZákvvӨos, he infers it from the IE stem *'kēko 'Green fodder, food', cf. Albert CARNOY, "Les suffixes toponymiques prégrecs," L'Antiquité Classique 29 (1960): 325-326. The Pelasgic origin, referring to the island of Zakynthos, is strongly ruled out by David A. HESTER, “"Pelasgian”-A New Indo-European Language?," Lingua 13 (1965): 353-354. Thus far, there was no attempt at explaining the name with reference to the Libyan city of Zakynthos, nor to the African (Semito-Hamitic) origins of the analysed name for 'turnip' or 'gourd.' 
considered incorrect and requiring an editorial intervention. The reason for this is quite mundane. The publishers of Hesychian lexicon, i.e. Marcus Musurus (ca. 1470-1517), Moriz Wilhelm Constantin Schmidt (1858-1868) and Kurt Latte (1891-1964), on the basis of the aforementioned Lydian gloss and the alleged (erroneous) reference to the island of Zakynthos, corrected the text of Codex Marcianus ( $\zeta \alpha \kappa \alpha v \theta i \delta \varepsilon \varsigma \mathrm{H})^{33}$ and introduced the discussed gloss into the editions of the Hesychian lexicon in the following form:

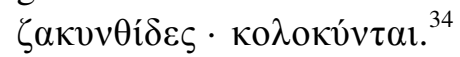

In our opinion, the amendment made by Musurus in the first edition of the Hesychian lexicon of 1514 (edition Aldina) and later repeated by

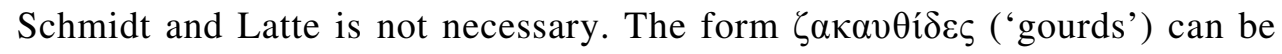
derived from the archetype $* \zeta \alpha \kappa \alpha \lambda \tau i \delta \varepsilon \varsigma$, which naturally stands in relation to the Thessalian form $\zeta \alpha \kappa \varepsilon \lambda \tau i ́ \delta \varepsilon \varsigma$ ('gourds' or 'turnips') and the Boeotian $\zeta \varepsilon \kappa \varepsilon \lambda \tau i ́ \delta \varepsilon \varsigma$ ('turnips'). ${ }^{35}$

Moreover, it cannot be ruled out that the variant $\zeta \alpha \kappa v v \theta i \delta \varepsilon \varsigma$, if we treat it

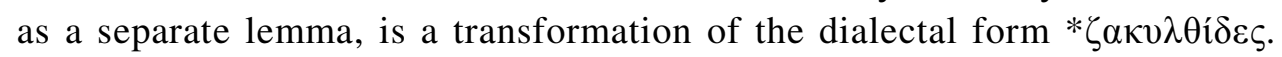
The consonant sequences $\lambda \tau, \lambda \theta$ underwent irregular (but relatively frequent) transformation into $v \tau, v \theta$, in particular in Western Greek dialects ${ }^{36}$, e.g. Gr.

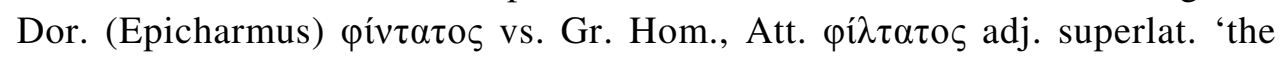
nicest, the most pleasant, the most beloved, the dearest'; Gr. Dor. (Alcman, Theocritus) $\beta \varepsilon \dot{\varepsilon} \tau \imath \sigma \tau o \varsigma$ vs. Gr. Att. $\beta \varepsilon \dot{\varepsilon} \lambda \tau \imath \sigma \tau \varsigma$ adj. superlat. 'the best, the most excellent ${ }^{37}$; Gr. Dor. $\dot{\varepsilon} v \theta \varepsilon \tilde{\varepsilon} v$ (inf. aor. II act.) vs. Gr. Att. $\dot{\varepsilon} \lambda \theta \varepsilon \tilde{\imath} v$, Cret. $\varepsilon \dot{v} \theta \varepsilon \tilde{\varepsilon} v$ (< PIE $* h_{l} l u d h-$ ), cf. Gr. Hom. $\ddot{\eta} \lambda v \theta$ ov 'I set off, I arrived. ${ }^{38}$

\footnotetext{
${ }^{33}$ Kurt LatTe, ed., Hesychii Alexandrini, Bd.II, 812-813. Codex Marcianus written around 1430 in Constantinople and currently kept in Venice (Biblioteca Nazionale Marciana, MSS Greci fondo antico No. 622), is the only preserved manuscript containing the lexicon of Hesychius of Alexandria. See Klaus Alpers, Ian C. Cunningham, eds., Hesychii Alexandriai Lexicon, vol. IV (Berlin-New York: Walter de Gruyter, 2009), XI.

${ }^{34}$ Hesychii Alexandrini Lexicon, post I. Albertum recensuit Moritz Schmidt, Bd. II (Ienae: sumptibus Frederici Maukii, 1860), 252; Kurt LATTE, ed., Hesychii Alexandrini, Bd. II, 257.

${ }^{35}$ It is worth noting here that the Boeotian form $\zeta \varepsilon \kappa \varepsilon \lambda \tau i \delta \varepsilon \varsigma$ arose from the older form $* \zeta \alpha \kappa \varepsilon \lambda \tau i ́ \delta \varepsilon \varsigma$ as a result of total regressive assimilation $(\alpha-\varepsilon>\varepsilon-\varepsilon)$. In turn, the discussed form $\zeta \alpha \kappa \alpha v \theta i \delta \varepsilon \varsigma(<* \zeta \alpha \kappa \alpha \lambda \tau i \delta \varepsilon \varsigma<* \zeta \alpha-\kappa \varepsilon \lambda \tau i \delta \varepsilon \varsigma)$ can be explained with the help of two phonological processes: progressive assimilation $(\alpha-\varepsilon>\alpha-\alpha)$ and subsequent velarization of the liquid consonant $\lambda$. Jurewicz quotes numerous Greek examples of assimilated vowels, Gramatyka historyczna, 67-68.

${ }^{36}$ Carl D. BucK, The Greek Dialects, 64-65.

${ }^{37}$ Eduard SchwYZER, Griechische Grammatik, Bd. I (München: C.H. Beck'sche Verlagsbuchhandlung, 1939), 213.

${ }^{38}$ Gustav MeYer, Griechische Grammatik (Leipzig: Verlag von Breitkopf \& Härtel, $1896^{3}$ ), 242; Eduard SchwYZER, Griechische, Bd. I, 213; Carl D. Bucк, The Greek Dialects, 65; Юрий
} 


\section{THE VELARISATION OF THE LIQUID CONSONANT $\Lambda$ [L] IN THE CRETAN DIALECT}

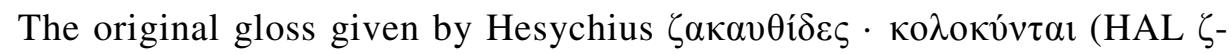
30), which cannot be analysed in isolation from the Thessalian gloss

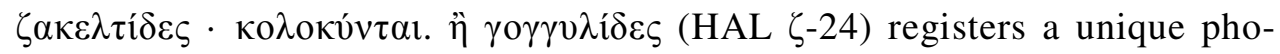
netic change $\lambda>v$, characteristic only of the dialects of central Crete. This process, consisting in the velarization of the general Greek phoneme $-\lambda-[1]$ at the end of a closed syllable and its regular transformation into the Cretan phoneme $\left[u{ }_{n}\right],{ }^{39}$ is perfectly evidenced in at least five Cretan glosses recorded by Hesychius of Alexandria:

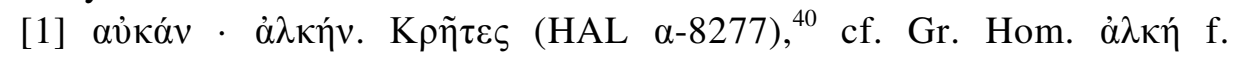
'physical strength, fortitude, bravery, valour" ${ }^{41}$;

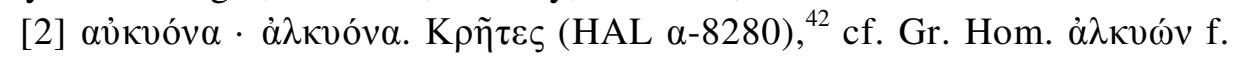
'kingfisher, Alcedo hispida L.';

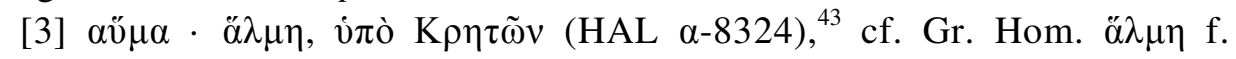
'saline water, sea; salt sediment; salt solution, brine';

В. Откупщиков [Yuriy V. ОткUPSнснікоV], Из истории индоевропейского словообразования (Ленинград: Издательство Ленинградского Университета, 1967), 177, 189.

${ }^{39}$ Gustav M. KleEmann, De universa Creticae dialecti indole adiecta glossarum Creticarum

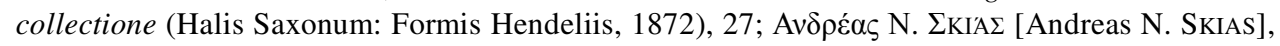

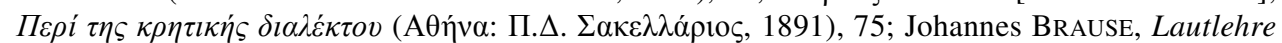
der kretischen Dialekte (Halle a. S.: Max Niemeyer, 1909), 173-175; Albert ThumB, Ernst KIECKERS, Handbuch der griechischen Dialekte, Bd. I (Heidelberg: Carl Winters Universitätsbuchhandlung, 1932²), 156; Antonín BARTONĚK, Classification of the West Greek Dialects at the Time about 350 B.C. (Prague: Academia, 1972), 152; Monique BILE, Le dialecte crétois ancien. Étude de la langue des inscriptions. Recueil des inscriptions postérieures aux IC (Paris: Libraire Orientaliste Paul Geuthner, 1988), 120. Although this phenomenon is unusual in Ancient Greek, Raymond Brown, Evidence for Pre-Greek Speech on Crete from Greek Alphabetic Sources (Amsterdam: Adolf M. Hakkert, 1985), 35, rightly emphasizes that the velarization of the liquid consonant [1] "is a common feature found in many languages (e.g. Old French, Modern Polish) and occurs in some varieties of spoken English (e.g. the London Cockney dialect)."

${ }^{40}$ Hesychii Alexandrini Lexicon, review et emendavit Kurt LATTE, Bd. I (Hauniae: Ejnar Munksgaard, 1953), 279.

${ }^{41}$ Gustav M. KleEmann, De universa Creticae dialecti indole, 27; Gustav Meyer, Griechische, 244; Eduard SCHWYZER, Griechische, vol. I, 212; Vittore PISANI, Manuale storico, 111;

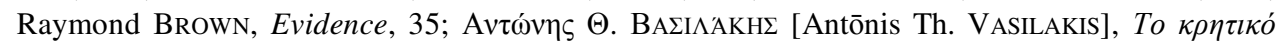

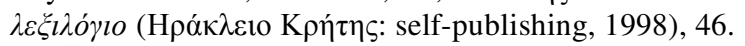

${ }^{42}$ Kurt Latte, ed., Hesychii Alexandrini, Bd. I, 280; Gustav M. KleEmann, De universa Creticae dialecti indole, 27; Gustav MEYER, Griechische, 244; Vittore PISANI, Manuale storico, 111; Raymond BROWN, Evidence, 35.

${ }^{43}$ Kurt LatTe, ed., Hesychii Alexandrini, Bd. I, 281; Gustav M. KleEmann, De universa Creticae dialecti indole, 27; Gustav MEYER, Griechische, 244; Vittore PISANI, Manuale storico, 111. 


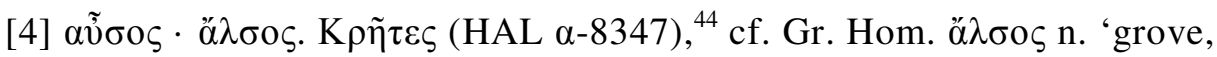
especially holy grove, holy circle.'

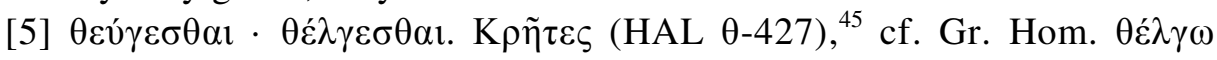
'enchant, seduce, deceive, delude; evoke something with magic.'

The Cretan origin is also attributed to some other glosses listed by Hesychius, which reveal the same phonetic process:

[6] $\alpha \hat{v} \gamma \varepsilon \tilde{\imath} v \cdot \dot{\alpha} \lambda \gamma \varepsilon \tilde{i} v($ Hal $\alpha-8231),{ }^{46}$ cf. Gr. Hom. $\dot{\alpha} \lambda \gamma \varepsilon \dot{\varepsilon} \omega$ 'suffer, feel pain; worry, hurt';

[7] $\varepsilon \dot{v} \theta \varepsilon \tilde{\imath} v \cdot \dot{\varepsilon} \lambda \theta \varepsilon \tilde{\imath} v($ HAL $\varepsilon-6863),{ }^{47}$ cf. Gr. Hom. $\ddot{\eta} \lambda v \theta$ ov, Att. $\tilde{\eta} \lambda \theta$ ov 'I set off, I arrived,' inf. aor. Act II. $\dot{\varepsilon} \lambda(v) \theta \varepsilon i \tilde{v}$.

We believe that the eighth case documenting the coarticulatory phenomenon that is unusual for Old Greek, can be found in the next gloss by Hesy-

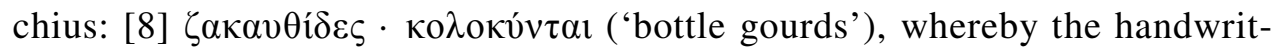

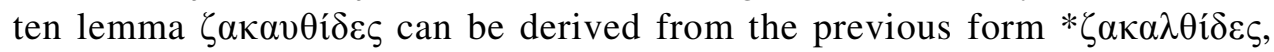
which is undoubtedly related to the Boeotian ( $\varepsilon \varepsilon \kappa \varepsilon \lambda \tau i ́ \delta \varepsilon \varsigma)$ and Thessalian term $(\zeta \alpha \kappa \varepsilon \lambda \tau i ́ \delta \varepsilon \varsigma)$.

\section{THE CRETAN EPIGRAPHIC MATERIAL AND THE VELARIZATION OF THE LIQUID CONSONANT}

The velarization of the Greek phoneme - $\lambda-$ [1] at the end of a closed syllable, combined with its subsequent vocalisation, is a specific phonetic process that has been repeatedly recorded in the inscriptions from Gortyna, Leben and Phaistos. ${ }^{48}$ The following epigraphic examples are evidence of the occurrence of the velar variant $[u[x]$ in the dialect of Central Crete:

\footnotetext{
${ }^{44}$ Kurt Latte, ed., Hesychii Alexandrini, Bd. I, 282; Gustav M. KleEmann, De universa Creticae dialecti indole, 27; G. MeYer, Griechische, 244; Vittore PISANI, Manuale storico, 111.

${ }^{45}$ Kurt Latte, ed., Hesychii Alexandrini, Bd. II, 318; Gustav M. KleEmann, De universa Creticae dialecti indole, 27; Gustav MEYER, Griechische, 244; Eduard SCHWYZER, Griechische, Bd. I, 212; Vittare PISANI, Manuale storico, 111; Raymond Brown, Evidence, 58.

${ }^{46}$ Kurt LatTe, ed., Hesychii Alexandrini, Bd. I, 278 ("Creticum”); Gustav M. KleEmann, De uni-

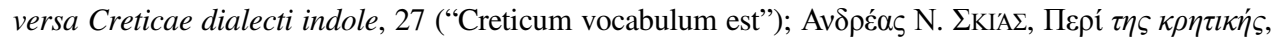
75; Gustav MeYER, Griechische, 244; Friedrich BeChtEl, Die griechischen Dialekte, Bd. II (Berlin:

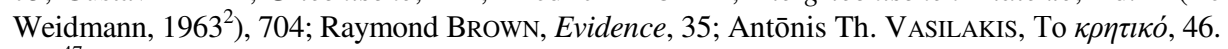

${ }^{47}$ Kurt Latte, ed., Hesychii Alexandrini, Bd. II, 225 ("Creticum”); Gustav M. KleEmann,

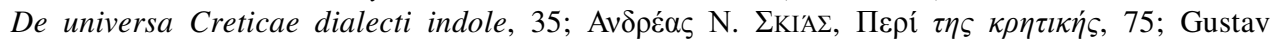
Meyer, Griechische, 244; Friedrich Bechtel, Die griechischen, Bd. II, 704; Raymond Brown,

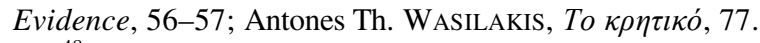

${ }^{48}$ Ernst FRAENKEL, "Index der kretischen Inschriften sowie Nachträgen und kurz Abriss der Laut-, Formen- und Wortbildungslehre des kretischen Dialekts," in Hermann CollitZ, O. HofFManN, Hrsg.,
} 
[9] $\alpha \delta \varepsilon v \pi ı \alpha$ nom. Pl. ${ }^{49}$ 'sisters' (Gortyn Code, $5^{\text {th }}$ century BCE) represents Gr. $\dot{\alpha} \delta \varepsilon \lambda \varphi \varepsilon \alpha i ́$ (= Att. $\dot{\alpha} \delta \varepsilon \lambda \varphi \alpha i ́$ f. Pl. 'sisters, relatives'). However, it is worth noting that in the same document there are as many as 13 mentions of the appellative $\dot{\alpha} \delta \varepsilon \lambda \pi \mathrm{ló} \varsigma \mathrm{m}$. 'brother' ${ }^{50}$ (< Gr. $\dot{\alpha} \delta \varepsilon \lambda \varphi \varepsilon o ́ \varsigma$, cf. Att. $\dot{\alpha} \delta \varepsilon \lambda \varphi o ́ \varsigma \mathrm{m}$. 'brother, relative, compatriot' ${ }^{51}$ );

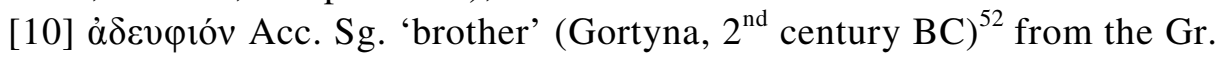

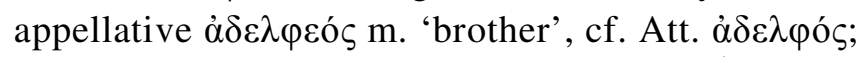

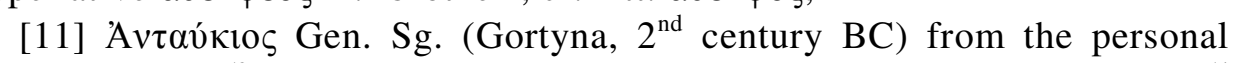

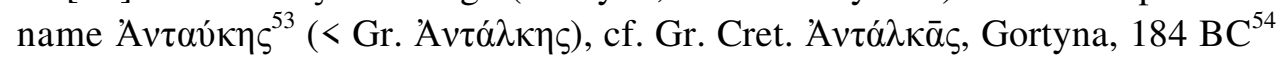

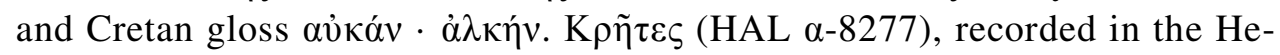
sychian lexicon;

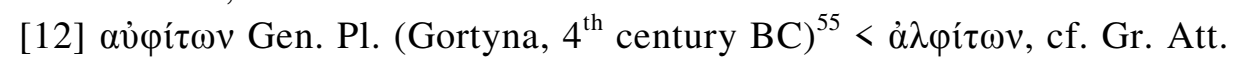

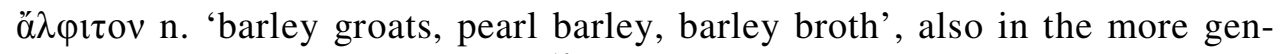
eral sense of 'flour, bread; food' ${ }^{56}$;

[13] غ̇ं $\varepsilon v \theta \omega \dot{~(G o r t y n a, ~} 2^{\text {nd }}$ century BC) ${ }^{57}<\dot{\varepsilon} \pi \varepsilon \lambda \theta \omega \dot{~} v$, cf. Hesychius' gloss

Sammlung Griechischer Dialekt-Inschriften, Bd. IV, H. 3 (Göttingen: Verlag von Vandenhoeck \& Ruprecht, 1915), 1066 (" $\lambda$ vor Konsonanten > v"); Carl D. Buck, THE Greek Dialects, 64; Monique BILE, Le dialecte crétois, 120. See also Moreno MoRANI, Introduzione alla linguistica greca. Il greco tra le lingue indeuropee (Alessandria: Edizioni dell’Orso, 1999), 82.

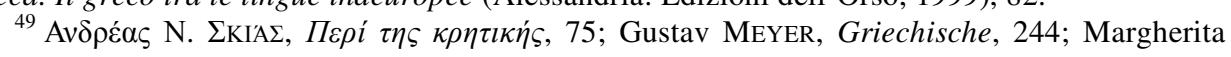
GuARDUCCI, ed., Inscriptiones Creticae opera et consilio Friderici Halbherr collectae, vol. IV: Tituli Gortynii (Roma: La Libreria dello Stato, 1950), 132, 159; Antonín BARTONĚK, Classification of the West Greek Dialects, 152; Inés Calero SeCAll, Leyes de Gortina, (Supplementa Mediterránea 2) (Madrid: Ediciones Clásicas, 2000), 172, 247. It should be noted that in the Gortyn Code, the grapheme $\pi$ is used for both the voiceless consonant [p] and the voiceless labial aspirate $\left[\mathrm{p}^{\mathrm{h}}\right]$.

${ }^{50}$ Antonín BARTONĚK, Classification of the West Greek Dialects, 152 explains the observed frequency of the form by the attachment to the traditional spelling: "The fact that the "regular" $\lambda$ forms are far more prevailing may be explained by the conservational power of the traditional orthography."

${ }^{51}$ Zofia ABramowiczówna, ed., Stownik, vol. I, 25; Henry G. LidDell, Robert ScotT, A GreekEnglish, 20-21; Oktawiusz JuREwICZ, Stownik, vol. I, 9; Franco MonTANARI, Vocabolario, 71.

${ }_{52}$ Margherita GuarducCI, ed., Inscriptiones Creticae, vol. IV, 284; Monique BILE, Le dialecte crétois, 120.

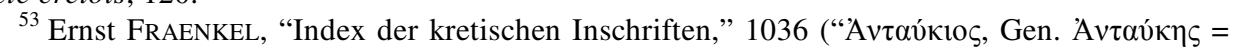

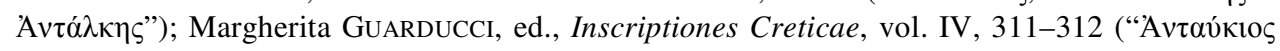

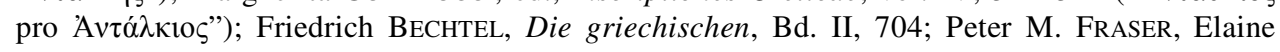
Matthews, A Lexicon of Greek Personal Names, vol. I (Oxford: Clarendon Press, 1987), 42; Monique BILE, Le dialecte crétois, 120.

${ }_{54}^{54}$ Peter M. Fraser, Elaine MATTHEws, A Lexicon, vol. I, 41.

${ }^{55}$ Margherita GuARduCCI, ed., Inscriptiones Creticae, vol. IV, 212 (inscr. no. 245), also

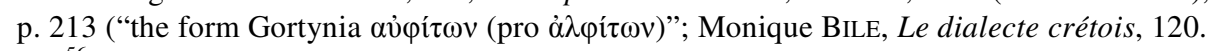

${ }^{56}$ Zofia AbramowiczównA, ed., Stownik, vol. I, 99; Oktawiusz Jurewicz, Stownik, vol. I, 32.

${ }^{57}$ Ernst Fraenkel, "Index der kretischen Inschriften," 1127; Margherita GuarduCCI, ed., 
$\varepsilon \dot{\varepsilon} \theta \varepsilon \tilde{\imath} v \cdot \dot{\varepsilon} \lambda \theta \varepsilon \tilde{\imath} v($ HAL $\varepsilon-6863)$;

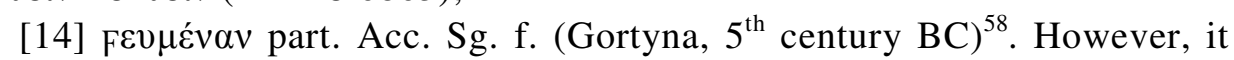
should be noted that the form $\kappa \alpha \tau \alpha \digamma \varepsilon \lambda \mu \varepsilon ́ v \bar{o} v$ (Gen. Pl.) appears twice in the Gortyn Code, and it still retains the phoneme [1];

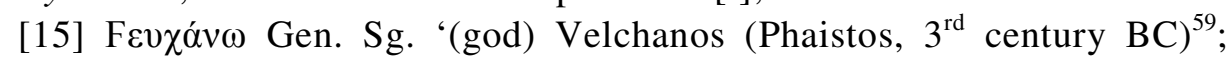

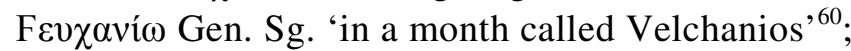

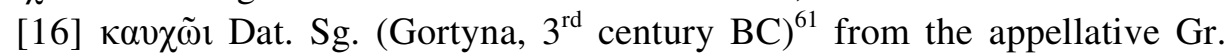
Cret. $\kappa \alpha \lambda \chi o ́ \varsigma$ m. 'bronze' (= Gr. Hom. $\chi \alpha \lambda \kappa o ́ \varsigma$ m. 'copper, bronze, gunmetal'), Gr. Myc. ka-ko m. 'bronze' ${ }^{62}$;

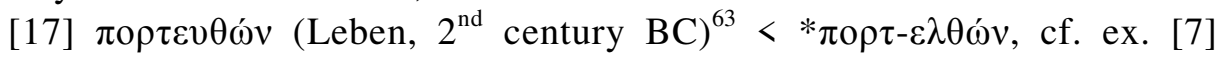
above. The first part of the compound contains the preposition Gr. Cret. $\pi$ o $\tau$ í 'towards, around, at ${ }^{64}$ created via metathesis of the liquid consonant

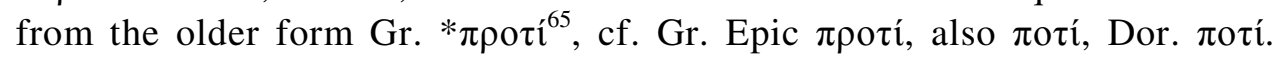
The apocope form of Gr. Ion. ${ }^{*} \pi \rho o \sigma i ́$ is Gr. Hom., Att.-Ion. $\pi \rho o ́ s$.

As documented by the above epigraphic material, the velarization of the liquid consonant [1] appeared already in the $5^{\text {th }}$ and $4^{\text {th }}$ centuries $\mathrm{BC}$ in Gortyna, and in the following centuries $\left(3^{\text {rd }}-2^{\text {nd }}\right.$ century BC) it spread to the surrounding towns (Phaistos, Leben). The velar pronunciation must have been quite common in the southern part of Central Crete, since the inscriptions contained numerous phonetic entries recording the local pronunciation $[\mathrm{u}] .{ }^{66}$

Inscriptiones Creticae, vol. IV, 231, 234; Monique BILE, Le dialecte crétois, 120.

${ }^{58}$ Ernst FrAENKEL, "Index der kretischen Inschriften," 1132; Margherita GUARDUCCI, ed., Inscriptiones Creticae, vol. IV, 183, 187; Monique BILE, Le dialecte crétois, 120.

59 Johannes BRAUSE, Lautlehre, 174; Margherita GUARDUCCI, ed., Inscriptiones Creticae opera et consilio Friderici Halbherr collectae, vol. I: Tituli Cretae Mediae praeter Gortynios (Romae: La Libreria dello Stato, 1935), 274. See also Ernst FrAENKEL, "Index der kretischen

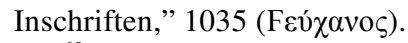

${ }^{60}$ Monique Bile, Le dialecte crétois, 120; Angelos Chaniotis, Die Verträge zwischen kretischen Poleis in der Hellenistischen Zeit (Stuttgart: Franz Steiner Verlag, 1996), 407. See also Krzysztof GęBURA, Menologia Graeca. Studium nazw miesięcy greckich (Siedlce: Wydawnictwo Uczelniane WSRP, 1996), 44.

${ }^{61}$ Ernst FrAENKEL, "Index der konkretischen Inschriften," 1139; Eduard ScHWYZER, Griechische, Bd. I, 212; Юрий В. ОткУПщикОВ, Из историu, 177; Monique BILE, Le dialecte crétois, 120.

${ }^{62}$ Francisco Aura Jorro, ed., Diccionario micénico, vol. I (Madrid: Consejo Superior de Investigaciones Científicas, 1985), 308-309.

${ }^{63}$ Margherita GuARDuCCI, ed., Inscriptiones Creticae, vol. I, 162; Monique BILE, Le dialecte crétois, 120.

${ }^{64}$ Ernst FrAENKEL, "Index der kretischen Inschriften," 1157.

${ }^{65}$ Monique BILE, Le dialecte crétois, 125.

${ }^{66}$ The velarization of the liquid consonant [1], limited to the position before the mid vowel [a] and the back vowels [o, u], also appears in the Cretan dialects of Modern Greek, cf. Niкó $\lambda \alpha o \varsigma$ 
THE CRETAN GENESIS OF THE HESYCHIAN GLOSS Z-30

The Cretan glosses [1-5], listed in the dictionary of Hesychius of Alexandria, as well as numerous epigraphic examples [9-17] recorded in several Cretan towns located in the southern part of Central Crete (inter alia, in Phaistos, Gortyna and Leben), prove conclusively that the discussed shift [1] $>$ [u] took place in the ancient Central Cretan dialects. It is thus not surprising that glosses [6-7], which are devoid of ethnic (dialectal) identification, are generally considered to be Cretan, or more precisely, Central Cretan.

The juxtaposition of the three related forms recorded in written sources-

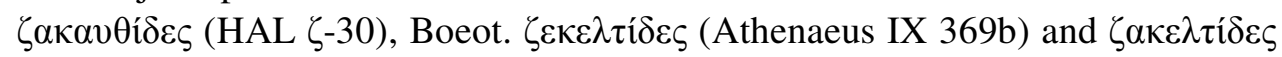
(Athenaeus IX 369b; HAL $\zeta-24$ ), allows to expand the Cretan lexical

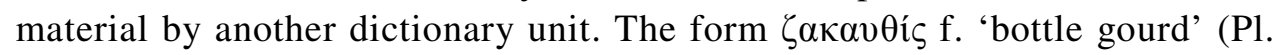
$\zeta \alpha \kappa \alpha v \theta i \delta \varepsilon \varsigma)$, preserved in the dictionary of Hesychius of Alexandria, has to be recognized as Cretan (similarly to the aforecited examples [1-7]), since it shows a typically Cretan phonetic transformation, i.e. the velarization of the liquid consonant [1] > [u]. This process is utterly unknown to other dialects of ancient Greece, which makes it easier to assign the correct ethnicity to

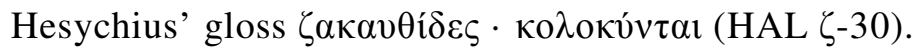

Although the Alexandrian lexicographer did not provide the gloss with

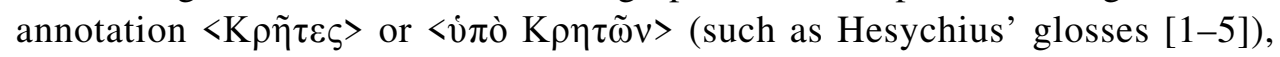
the lemma contains very specific phonetic features that unambiguously indicate its Cretan (or more precisely-Central Cretan) origin, see glosses [6-7], which the editor Kurt Latte eagerly provided with the unambiguous qualifier "Creticum.",67

\section{THE MYCENAEAN GENESIS OF THE CRETAN TERM}

In the previous subsections we have tried to demonstrate, on the basis of rich lexical and epigraphic material, that the gloss $\zeta \alpha \kappa \alpha v \theta i \delta \varepsilon \varsigma \cdot \kappa о \lambda о \kappa v ́ v \tau \alpha 1$ (HAL $\zeta-30$ ) should be attributed to the Cretans living in the central part of the island, especially around Gortyna, Phaistos and Leben. The research thesis is based on the phonological features of the local idiolect, which was characterized by the velarization of the liquid consonant $\lambda$ [1], i.e. the shift of the phoneme [1] in [u], which was vocalized in a suitable environment.

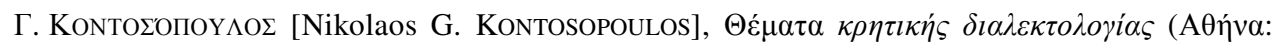

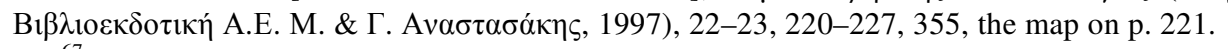

${ }^{67}$ Kurt LatTe, ed., Hesychii Alexandrini, Bd. I, 278; Bd. II, 225. 


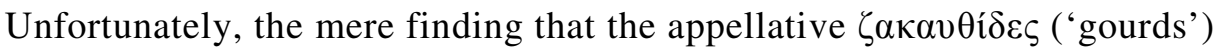
belonged to the Central Cretan idiolect does not solve all the problems. In the examined gloss there appears a coronal aspirate $\left[\mathrm{t}^{\mathrm{h}}\right]$ or a dental spirant $[\theta]$, while in the related forms-Boeotian $\zeta \varepsilon \kappa \varepsilon \lambda \tau i ́ \delta \varepsilon \varsigma$ ('turnips') and Thessalian $\zeta \alpha \kappa \varepsilon \lambda \tau i \delta \varepsilon \varsigma$ ('gourds')—there appears the voiceless dental plosive [t]. Since the ancient Cretan dialect does not have the assibilation of the voiceless dental consonant $\tau$ [t] before the front vowel - 1 - [i] and there is no further transformation into the spirant $[\theta]$ or $[s]^{68}$, it should be assumed that the distinguished Central Cretan form $\zeta \alpha \kappa \alpha v \theta i \delta \varepsilon \varsigma$ is not native, but borrowed from another Greek dialect ${ }^{69}$ in which the spirantization of dental consonants

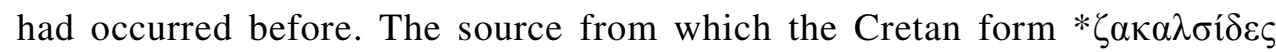
(from which the documented Central Cretan form $\zeta \alpha \kappa \alpha v \theta i \delta \varepsilon \varsigma$ developed) was borrowed is most probably the Old Mycenaean dialect, ${ }^{70}$ used in Crete in the second half of the second millennium BC. After the conquest of Crete by the Dorians, the Mycenaean dialect gave way to the local Doric dialect, leaving some (not very numerous) traces in the lexical and onomastic layer.

\footnotetext{
${ }^{68}$ The retention of [t] before the front vowel [i] is characteristic of all Western Greek dialects, as well as some Aeolian dialects (i.e. Thessalian and Boeotian), see Carl D. BucK, The Greek Dialects, 57-58; Helmut Rix, Historische Grammatik des Griechischen. Laut- und Formenlehre (Darmstadt: Wissenschaftliche Buchgesellschaft, 1992), 89.

${ }^{69}$ The non-Doric elements present in the Cretan dialect are discussed in Claude BRIXHE, "La langue comme reflet de l'histoire ou les éléments non doriens du dialecte crétois," in: Claude BRIXHE, ed., Sur la Crète antique. Histoire, écritures, langues (Nancy: Presses Universitaires de Nancy, 1991), 43-77. See also Ronald F. WilletTs, "Arcado-Cypriot Traces in the Ancient

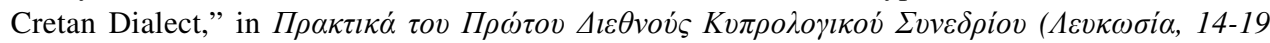

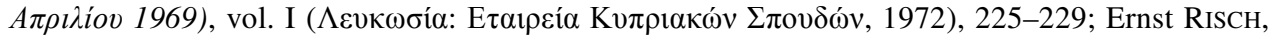
"La posizione del dialetto dorico," in Domenico MuSTI, a cura di, Le origini dei greci. Dori e mondo egeo (Roma-Bari: Editori Laterza, 1991), 17-18, 31.

${ }^{70}$ In the Mycenaean dialect, already in the second millennium BC, there occurred the assibilation of the dental consonants $\left[\mathrm{t}^{\mathrm{h}}\right]$ and $[\mathrm{t}]$ preceding the front vowel [i], see Michel LEJEUNE, "La posizione dialettale del greco miceneo," in Gianfranco MADDOLI, a cura di, La civiltà micenea. Guida storica e critica (Roma-Bari: Editori Laterza, 1992), 125-126. Pre-Doric forms of the name of the god Poseidon, containing the fricative[s] are discussed in detail by Robert SUCHARSKI, Posejdon $w$ świetle tekstów tabliczek $w$ greckim piśmie linearnym B (Warszawa: KNoKA PAN, 2000), 19-22; he drew the conclusion that the Peloponnese Dorians (including Spartans) adopted this theonym from the Mycenaean Greeks. A similar view has recently been expressed by Araceli STRIANO, "Laconian, Messenian," in Georgios K. GIANNAKIS, ed., Encyclopedia of Ancient Greek Language and Linguistics, vol. II (Leiden-Boston: Brill, 2014), 287: "Probable substratum features such as the term Pohoidaia 'the games in honour of Poseidon' seem to support the idea that Laconians settled in a region previously inhabited by speakers of the so-called "Achaean" dialect". See also John CHADWICK, "I Dori and la creazione dei dialetti greci," in Domenico Musti, a cura di, Le origini dei greci. Dori e mondo egeo (Roma-Bari: Editori Laterza, 1991), 9; Carl D. BuCK, The Greek Dialects, 58; Moreno MoRANI, Introduzione alla linguistica greca, 101.
} 


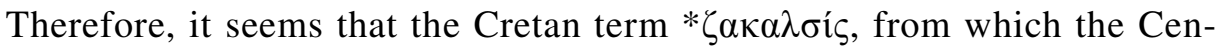

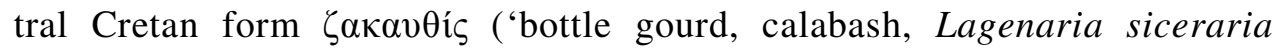
Standl.') is derived, was borrowed from the Achaean (Mycenaean) source. ${ }^{71}$ It is worth noting here that in the dialects of Central Crete, the grapheme $\theta$ often renders the Greek spirant [s], cf. Gr. Cret. (Gortyna, $3^{\text {rd }}$ century BC) $\pi$ ó $\lambda \imath \imath \imath$ (= Gr. Ion. $\pi$ ó $\lambda \imath \sigma \imath$ ) Dat. Pl. 'cities' (< PGr. * $\pi$ ó $\lambda \imath \sigma \imath)$; Gr. Cret.

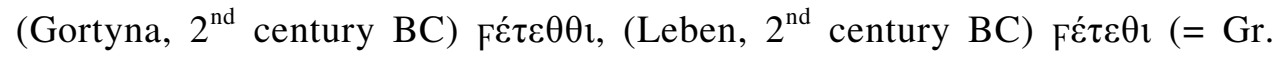

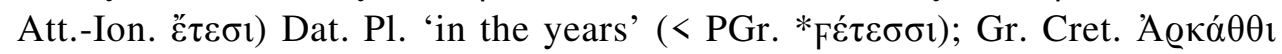

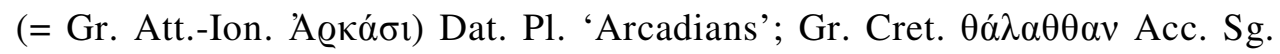

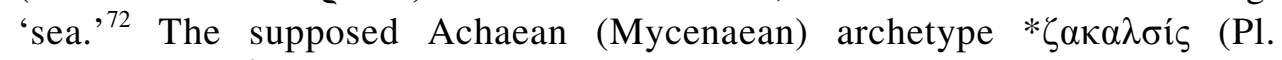
$* \zeta \alpha \kappa \alpha \lambda \sigma i \delta \varepsilon \varsigma)^{73}$ demonstrates a striking correspondence with the preserved

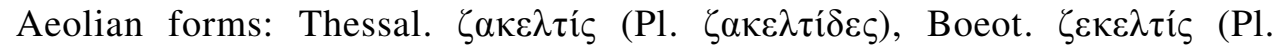
$\zeta \varepsilon \kappa \varepsilon \lambda \tau i ́ \delta \varepsilon \varsigma)$. Since Achaean and Aeolian dialects reveal a whole set of phonological, inflectional, word-forming and lexical similarities ${ }^{74}$ the presented convergence should be generally recognized.

\section{BIBLIOGRAPHY}

Abramowiczówna, Zofia, ed. Stownik grecko-polski, vols. I-IV. Warszawa: Państwowe Wydawnictwo Naukowe, 1958-1965.

Adrados, Francisco Rodríguez, ed. Diccionario griego-español, vol. IV. Madrid: Consejo Superior de Investigaciones Científicas, 1994.

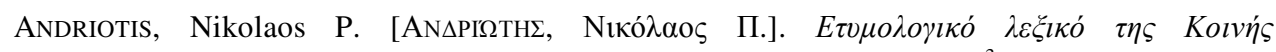

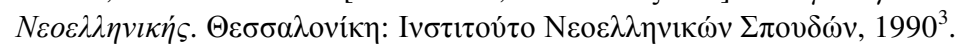

ANDRIOTIS, Nikolaos. Lexikon der Archaismen in neugriechischen Dialekten. Wien: Verlag der Österreichischen Akademie der Wissenschaften, 1974.

\footnotetext{
${ }^{71}$ In the preserved Mycenaean vocabulary, no word begins with the prefix $\delta 1 \alpha-$, which in Linear B writing should be written as $d i-j a-\left(d i-a\right.$ - or possibly $\left.d i-a_{2^{-}}\right)$. However, there are examples containing the prefix za- [ca-], e.g. Gr. Myc. za-e-to-ro (PY An 610.12); Gr. Myc. za-ki-ri-

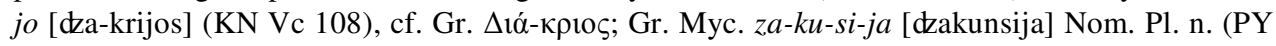

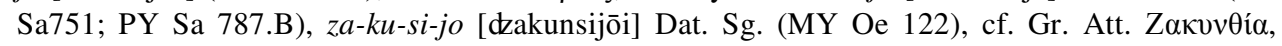

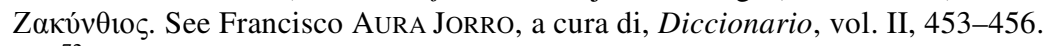

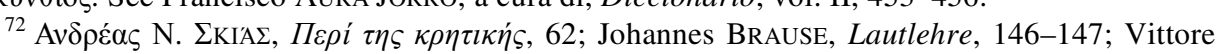
PisAnI, Manuale storico, 110-111; Monique BILE, Le dialecte crétois, 196.

${ }^{73}$ It is worth noting that the Mycenaean forms $z a-k u$-si-ja and $z a-k u$-si-jo demonstrate both the prefix $z a$ - [ca-] and the assibilation of the dental consonant $\left[\mathrm{t}^{\mathrm{h}}\right]$ to $[\mathrm{s}]$ when followed by the

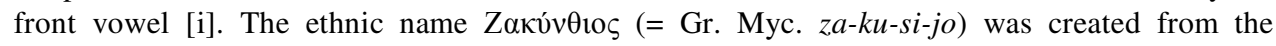
nesonym Zákvv $\theta$ os, which-according to Vladimir I. GEORGIEv, Introduzione alla storia delle lingue indeuropee (Roma: Edizioni dell'Ateneo, 1966), 55, 179, 207-is a complex formation

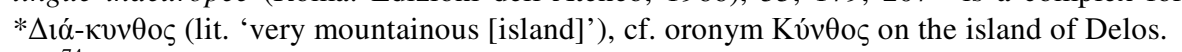

${ }^{74}$ Moreno MoRANI, Introduzione alla linguistica greca, 101-102, 110-112.
} 
AthenAeus. The Deipnosophists, vol. 4, with an English translation by Charles Burton Gulick. London: William Heinemann - Cambridge, Mass.: Harvard University Press, 1961 (http://penelope.uchicago.edu/Thayer/E/Roman/Texts/Athenaeus/home.html).

Aura Jorro, Francisco, ed. Diccionario micénico, vols. I-II. Madrid: Consejo Superior de Investigaciones Científicas, 1985-1993.

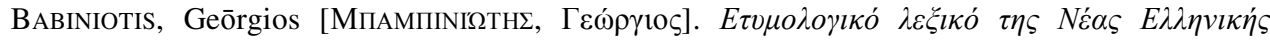

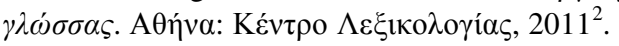

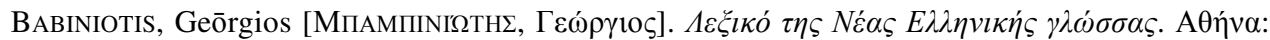

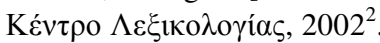

BARTONĚK, Antonín. Chréstomatie starořeckých nářečních nápisů. Brno: Masarykova Univerzita, 2011.

BARTONĚK, Antonín. Classification of the West Greek Dialects at the Time about 350 B.C. Prague: Academia, 1972.

Bechtel, Friedrich. Die griechischen Dialekte, Bd. I-II. Berlin: Weidmann, 1963².

BEEKES, Robert. Etymological Dictionary of Greek, vol. I-II. Leiden-Boston: Brill, 2010.

BeKKer, Immanuel, ed. Anecdota Graeca, Bd. I: Lexica Segueriana. Berolini: G.C. Nauck, 1814.

BENSELER, Gustav E. Wörterbuch der griechischen Eigennamen. Braunschweig: Verlag von Friedrich Vieweg und Sohn, $1884^{3}$.

BILE, Monique. Le dialecte crétois ancien. Étude de la langue des inscriptions. Recueil des inscriptions postérieures aux IC. Paris: Libraire Orientaliste Paul Geuthner, 1988.

BOISACQ, Émile. Dictionnaire étymologique de la langue grecque étudiée dans ses rapports avec les autres langues indo-européennes. Heidelberg: Carl Winter-Paris: Libraire C. Klincksieck, 1916.

BRAUSE, Johannes. Lautlehre der kretischen Dialekte. Halle a. S.: Max Niemeyer, 1909.

BRIXHE, Claude. "La langue comme reflet de l'histoire ou les éléments non doriens du dialecte crétois." In Claude BRIXHE, ed. Sur la Crète antique. Histoire, écritures, langues, 43-77. Nancy: Presses Universitaires de Nancy, 1991.

Brown, Raymond. Evidence for Pre-Greek Speech on Crete from Greek Alphabetic Sources. Amsterdam: Adolf M. Hakkert, 1985.

Buck, Carl D. The Greek Dialects. Grammar, Selected Inscriptions, Glossary. Bristol: Bristol Classical Press, 2009.

Calero SeCall, Inés. Leyes de Gortina. (Supplementa Mediterránea 2). Madrid: Ediciones Clásicas, 2000.

CARnoy, Albert. "Les suffixes toponymiques pré-grecs." L'Antiquité Classique 29 (1960): 319-336.

CARnoy, Albert. Dictionnaire étymologique des noms grecs de plantes. Louvain: Publications Universitaires-Institut Orientaliste, 1959.

ChaDwick, John. "I Dori e la creazione dei dialetti greci." In Domenico Musti, a cura di. Le origini dei greci. Dori e mondo egeo, 3-12. Roma-Bari: Editori Laterza, 1991.

Chaniotis, Angelos. Die Verträge zwischen kretischen Poleis in der hellenistischen Zeit. Stuttgart: Franz Steiner Verlag, 1996.

Chantraine, Pierre. Dictionnaire étymologique de la langue grecque. Histoire des mots, vols. I-IV. Paris: Éditions Klincksieck, 1968-1980. 
Colvin, Stephen. A Historical Greek Reader. Mycenaean to the Koiné. Oxford-New York: Oxford University Press, 2007.

DiosCóRIDES. Plantas y remedios medicinales (De materia medica, libros I-III). Introducción, traducción y notas de Manuela. GARCía VALDÉs. Madrid: Editorial Gredos, 1998.

DvoretskiY, Iosif Ch. [ДвоРЕцКий Иосиф X.]. Древнегреческо-русский словарь, т. I-II. Москва: Государственное Издательство Иностранных и Национальных Словарей, 1958.

EgetMeYer, Markus. Wörterbuch zu den Inschriften im kyprischen Syllabar. Berlin-New York: Walter de Gruyter, 1992.

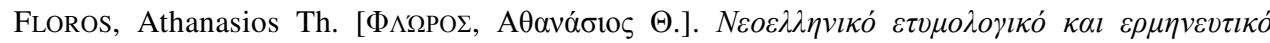

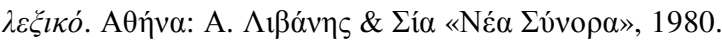

FRAENKEL, Ernst. "Index der kretischen Inschriften nebst Nachträgen und kurzem Abriss der Laut-, Formen- und Wortbildungslehre des kretischen Dialekts." In Hermann ColLiTZ, O. Hoffmann, Hrsg. Sammlung Griechischer Dialekt-Inschriften, Bd. 4, H. 3, 1030-1208. Göttingen: Verlag von Vandenhoeck \& Ruprecht, 1915.

Fraser, Peter M., Elaine Matthews. A Lexicon of Greek Personal Names, vol. I. Oxford: Clarendon Press, 1987.

FRISK, Hjalmar. Griechisches etymologisches Wörterbuch, Bd. I-III. Heidelberg: Carl Winter, 1960-1972.

GeNAust, Helmut. Etymologisches Wörterbuch der botanischen Pflanzennamen. Hamburg: Nikol Verlagsgesellschaft, $2005^{3}$.

GeORGIEv, Vladimir I. Introduzione alla storia delle lingue indeuropee. Roma: Edizioni dell'Ateneo, 1966.

GĘBURA, Krzysztof. Menologia Graeca. Studium nazw miesięcy greckich. Siedlce: Wydawnictwo Wyższej Szkoły Rolniczo-Pedagogicznej, 1996.

GoRCZYŃSKI, Tadeusz, ed. Rośliny użytkowe. Warszawa: Wiedza Powszechna, 1961.

GUARDUCCI, Margherita. Inscriptiones Creticae opera et consilio Friderici Halbherr collectae, vols. I-IV. Romae: La Libreria dello Stato, 1935-1950.

GUSMANI, Roberto. Lydisches Wörterbuch mit grammatischer Skizze und Inschriftensammlung. Heidelberg: Carl Winter, 1964.

Hester, David A. “Pelasgian”-A New Indo-European Language?” Lingua 13 (1965): 335-384.

HoFmann, Johann B. Etymologisches Wörterbuch des Griechischen. München: Verlag von R. Oldenbourg, 1950.

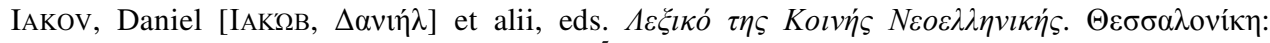

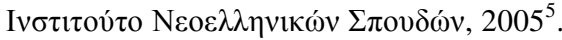

JUREwICZ, Oktawiusz. Gramatyka historyczna języka greckiego. Warszawa: Wydawnictwo Naukowe PWN, $1999^{2}$.

JUREwICZ, Oktawiusz. Stownik grecko-polski, vols. I-II. Warszawa: Wydawnictwo Szkolne PWN, 2000.

KaCZYŃSKA, Elwira, Krzysztof T. WITCZAK. "Cypryjski epigram na wotywnym reliefie z Golgoj (ICS no. 264).” In Krystyna BARTol, Jerzy DanielewiCz, eds. Epigram grecki i taciński w kulturze Europy. Konferencja ogólnopolska, Poznań, 11-12 grudnia 1995, 125-147. Poznań: Wydawnictwo Naukowe UAM, 1997. 
KACZYŃSKA, Elwira. ““'Cieszcie się kozy! Rozejm ogłasza bogini”. Uwagi krytyczne do jednego z epigramatów Kallimacha (62 Pfeiffer = 61 Gow-Page).” Meander 54, is. 5 (1999): 421-428.

Khorikov, Ivan P., Michail G. MALev [ХоРиков Иван П., Михаил Г. МАлев]. Новогреческорусский словарь. Москва: Издательство «Русский Язык», 1980.

KleEmann, Gustav M. De universa Creticae dialecti indole adiecta glossarum Creticarum collectione. Halis Saxonum: Formis Hendeliis, 1872.

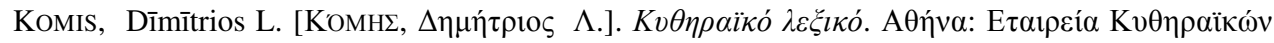

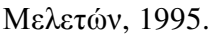

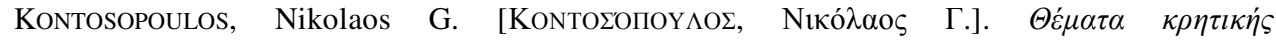

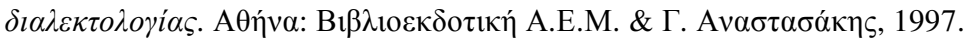

LATTE, Kurt, ed. Hesychii Alexandrini Lexicon, Bd. I-II. Hauniae: Ejnar Munksgaard, 1953-1966.

LeJEune, Michel. "La posizione dialettale del greco miceneo.” In Gianfranco MADDOLI, a cura di. La civiltà micenea. Guida storica e critica, 121-126. Roma-Bari: Editori Laterza, 1992.

LidDELl, Henry G., Robert ScotT. A Greek-English Lexicon. With a revised supplement. Oxford: Clarendon Press, 1996.

MeIneKe, August, ed. Stephani Byzantinii Ethnicorum quae supersunt. Chicago (Illinois): Ares Publishers, 1992.

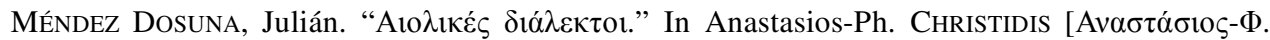

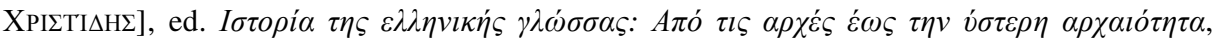

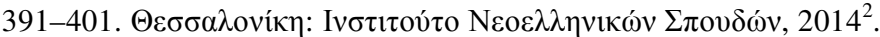

MEYER, Leo. Handbuch der griechischen Etymologie, Bd. I-IV. Leipzig: Verlag von S. Hirzel, 1901.

MeYer, Gustav. Griechische Grammatik. Leipzig: Verlag von Breitkopf \& Härtel, $1896^{3}$.

MontANARI, Franco. Vocabolario della lingua greca. Milano: Loescher Editore, 2003.

MoRANI, Moreno. Introduzione alla linguistica greca. Il greco tra le lingue indeuropee. Alessandria: Edizioni dell'Orso, 1999.

OткUPSнснікоv, Yuriy V. [Откупщиков, Юрий В.]. Из истории индоевропейского словообразования. Ленинград: Издательство Ленинградского Университета, 1967.

PISANI, Vittore. Manuale storico della lingua greca. Brescia: Paideia Editrice, 1973².

PISZCZEK, Zdzisław, ed. Mała encyklopedia kultury antycznej. Warszawa: PWN, 19907.

PODBIELKOwSKI, Zbigniew. Stownik roślin użtkowych. Warszawa: Państwowe Wydawnictwo Rolnicze i Leśne, $1985^{5}$.

POKORNY, Julius. Indogermanisches etymologisches Wörterbuch, Bd. I. Bern-München: Francke Verlag, 1959.

PRELlwITZ, Walther. Etymologisches Wörterbuch der griechischen Sprache. Göttingen: Vandenhoeck und Ruprecht, 1892.

QuATTORDIO MoRESCHINI, Adriana. Le formazioni nominali greche in -nth-. Roma: Edizioni dell'Ateneo, 1984.

RISCH, Ernst. "La posizione del dialetto dorico." In Domenico Musti, a cura di. Le origini dei greci. Dori e mondo egeo, 13-35. Roma-Bari: Editori Laterza, 1991.

Rix, Helmut, Hrsg. Lexikon der indogermanischen Verben. Die Wurzeln und ihre Primärstammbildungen. Wiesbaden: Dr. Ludwig Reichert Verlag, 2001². 
RIX, Helmut. Historische Grammatik des Griechischen. Laut- und Formenlehre. Darmstadt: Wissenschaftliche Buchgesellschaft, 1992.

RoHLFs, Gerhard. Lexicon Graecanicum Italiae inferioris. Etymologisches Wörterbuch der unteritalienischen Gräzität. Tübingen: Max Niemeyer Verlag, $1964^{2}$.

SCHMIDT, Moritz, ed. Hesychii Alexandrini Lexicon, Bd. II. Ienae: sumptibus Frederici Maukii, 1860.

SCHRADER, Otto, Alfons NeHRING. Reallexikon der indogermanischen Altertumskunde, Bd. I-II. Berlin-Leipzig: Walter de Gruyter, 1917-1929.

SCHWYZER, Eduard. Griechische Grammatik, Bd. I. München: C.H. Beck'sche Verlagsbuchhandlung, 1939.

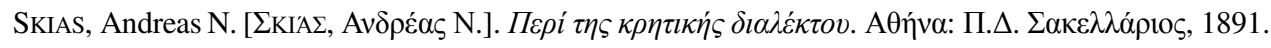

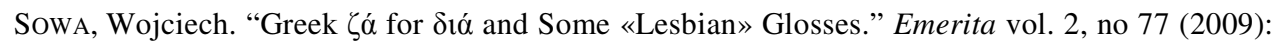
271-294.

Striano, Araceli. "Laconian, Messenian." In Georgios K. GiannAKIs, ed. Encyclopedia of Ancient Greek Language and Linguistics, vol. II, 287-288. Leiden-Boston: Brill, 2014.

SUCHARSKI, Robert. Posejdon w świetle tekstów tabliczek $w$ greckim piśmie linearnym B. Warszawa: Komitet Nauk o Kulturze Antycznej PAN, 2000.

Thumb, Albert, Ernst KIECKers. Handbuch der griechischen Dialekte, Bd. I. Heidelberg: Carl Winters Universitätsbuchhandlung, $1932^{2}$.

van WindeKens, Albert J. Contribution à l'étude de l'onomastique pélasgique. Louvain: Publications Universitaires-Institut Orientaliste, 1954.

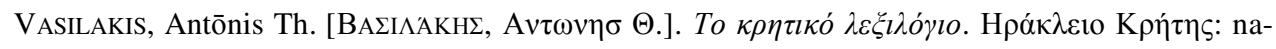
kładem autora, 1998.

VENDRYeS, Joseph. Traité de grammaire comparée des langues classiques. Paris: Librairie Ancienne Honoré Champion, 1960.

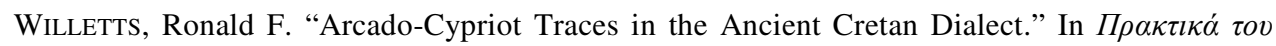

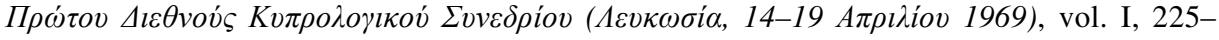

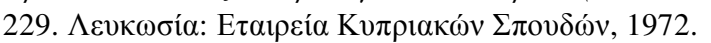

THE THESSALIAN AND CRETAN NAME FOR 'BOTTLE GOURD’

Summary

In his work Deipnosophistae (IX 369b), Athenaeus discusses four Greek names for turnip,

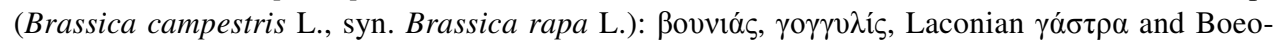

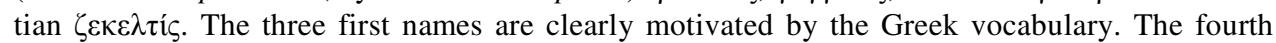
term remains obscure in terms of its etymology and word-formation. According to Athenaeus (IX 369b), two Greek writers, Amerias and Timachidas, refer to a dialectal (evidently Thessalian)

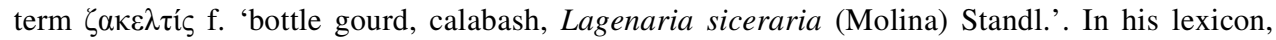

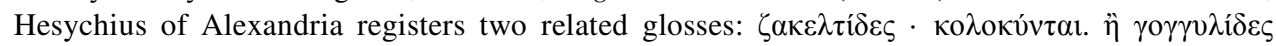

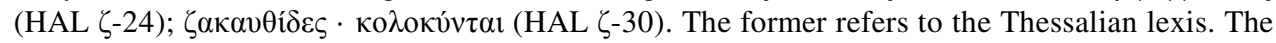

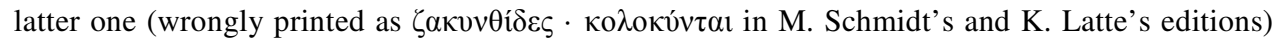
demonstrates a shift of the liquid consonant $\lambda[1]$ to [u]. which is a typical Cretan phenomenon,

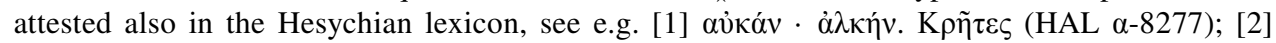

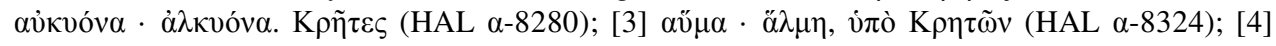




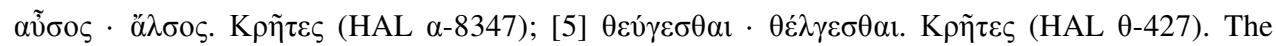
same phonological process of the velarization of $* \lambda[1]$ is also registered in epigraphic texts found in three towns of Central Crete (Gortyna, Leben, Phaistos). Thus, it seems that the Hesychian

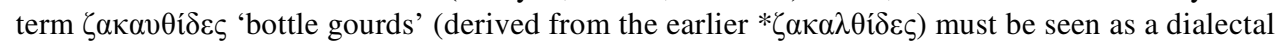
form typical of Central Cretan.

Key words: botanical names; Cretan dialect; Greek dialectology; Greek vocabulary.

\section{Translated by Rafat Augustyn}

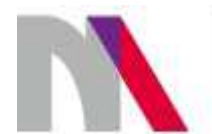

The preparation of the English version of Roczniki Humanistyczne (Annals of Arts) and its publication in electronic databases was financed under contract no. 836/P-DUN/2018 from the resources of the Minister of Science and Higher Education for the popularization of science. 